\title{
Recommendations for competing sexual-asexually typified generic names in Sordariomycetes (except Diaporthales, Hypocreales, and Magnaporthales)
}

Martina Réblová ${ }^{1}$, Andrew N. Miller ${ }^{2}$, Amy Y. Rossman ${ }^{3}$, Keith A. Seifert ${ }^{4}$, Pedro W. Crous ${ }^{5}$, David L. Hawksworth ${ }^{6,7,8}$, Mohamed A. Abdel-Wahab ${ }^{9}$, Paul F. Cannon ${ }^{8}$, Dinushani A. Daranagama ${ }^{10}$, Z. Wilhelm De Beer ${ }^{11}$, Shi-Ke Huang $^{10}$, Kevin D. Hyde $^{10}$, Ruvvishika $^{2}$ Jayawardena ${ }^{10}$, Walter Jaklitsch ${ }^{12,13}$, E. B. Gareth Jones ${ }^{14}$, Yu-Ming Ju ${ }^{15}$, Caroline Judith ${ }^{16}$, Sajeewa S. N. Maharachchikumbura ${ }^{17}$, Ka-Lai Pang ${ }^{18}$, Liliane E. Petrini' ${ }^{19}$, Huzefa A. Raja ${ }^{20}$, Andrea I Romero ${ }^{21}$, Carol Shearer ${ }^{2}$, Indunil C. Senanayake ${ }^{10}$, Hermann Voglmayr ${ }^{13}$, Bevan S. Weir ${ }^{22}$, and Nalin N. Wijayawarden ${ }^{10}$

1'Department of Taxonomy, Institute of Botany of the Academy of Sciences of the Czech Republic, Průhonice 252 43, Czech Republic ${ }^{2}$ Illinois Natural History Survey, University of Illinois, Champaign, Illinois 61820, USA

3Department of Botany and Plant Pathology, Oregon State University, Corvallis, Oregon 97331, USA; *corresponding author e-mail: amydianer@ yahoo.com

${ }^{4}$ Ottawa Research and Development Centre, Biodiversity (Mycology and Microbiology), Agriculture and Agri-Food Canada, 960 Carling Avenue, Ottawa, Ontario K1A 0C6 Canada

${ }^{5}$ CBS-KNAW Fungal Biodiversity Institute, Uppsalalaan 8, 3584 CT Utrecht, The Netherlands

${ }^{6}$ Departamento de Biología Vegetal II, Facultad de Farmacia, Universidad Complutense, Plaza de Ramón y Cajal s/n, Madrid 28040, Spain

${ }^{7}$ Department of Life Sciences, The Natural History Museum, Cromwell Road, London SW7 5BD, UK

${ }^{8}$ Comparative Plant and Fungal Biology, Royal Botanic Gardens, Kew, Surrey, TW9 3DS, UK

${ }^{9}$ Department of Botany and Microbiology, Faculty of Science, Sohag University, Sohag 82524, Egypt

${ }^{10}$ Center of Excellence in Fungal Research, School of Science, Mae Fah Luang University, Chiang Rai 57100, Thailand

${ }^{11}$ Department of Microbiology and Plant Pathology, University of Pretoria, Pretoria 0002, South Africa

${ }^{12}$ Institute of Forest Entomology, Forest Pathology and Forest Protection, Department of Forest and Soil Sciences, BOKU-University of Natural Resources and Life Sciences, Vienna, Austria

${ }^{13}$ Division of Systematic and Evolutionary Botany, Department of Botany and Biodiversity Research, University of Vienna, Vienna, Austria ${ }^{14}$ Department of Botany and Microbiology, College of Science, King Saud University, P.O. Box 2455, Riyadh 11451, Saudi Arabia

${ }^{15}$ Institute of Plant and Microbial Biology, Academia Sinica, Nankang, Taipei 115 29, Taiwan

${ }^{16}$ Department of Mycology, Institute of Ecology, Evolution and Diversity, Goethe-University, Max-von-Laue-Str. 13, 60438 Frankfurt am Main, Germany ${ }^{17}$ Department of Crop Sciences, College of Agricultural and Marine Sciences, Sultan Qaboos University, PO Box 8, 123 Al Khoud, Oman

${ }^{18}$ Institute of Marine Biology and Centre of Excellence for the Oceans, National Taiwan Ocean University, 2 Pei-Ning Road, Keelung 20224, Taiwan (ROC)

${ }^{19}$ Via al Perato 15c, CH-6932 Breganzona, Switzerland

${ }^{20}$ Department of Chemistry and Biochemistry, 457 Sullivan Science Building, University of North Carolina, Greensboro, NC 27402-6170, USA

${ }^{21}$ Instituto de Micología y Botánica, UBA-CONICET, Departamento de Biodiversidad y Biología Experimental, Facultad de Ciencias Exactas y Naturales, Universidad de Buenos Aires, Pabellón II, Piso 4 ${ }^{\circ}$ Lab 6, Av. Int. Güiraldes 2620. Ciudad Universitaria, C1428EHA, Buenos Aires, Argentina

${ }^{22}$ Manaaki Whenua Landcare Research, Private Bag 92170, Auckland, New Zealand

Abstract: With the advance to one scientific name for each fungal species, the generic names in the class Sordariomycetes typified by sexual and asexual morphs are evaluated based on their type species to determine if they compete with each other for use or protection. Recommendations are made for which of the competing generic names should be used based on criteria such as priority, number of potential names changes, and frequency of use. Some recommendations for wellknown genera include Arthrinium over Apiospora, Colletotrichum over Glomerella, Menispora over Zignoëlla, Microdochium over Monographella, Nigrospora over Khuskia, and Plectosphaerella over Plectosporium. All competing generic names are listed in a table of recommended names along with the required action. If priority is not accorded to sexually typified generic names after 2017, only four names would require formal protection: Chaetosphaerella over Oedemium, Diatrype over Libertella, Microdochium over Monographella, and Phaeoacremonium over Romellia and Togninia. Concerning species in the recommended genera, one replacement name (Xylaria benjaminii nom. nov.) is introduced, and the following new combinations are made: Arthrinium sinense, Chloridium caesium, C. chloroconium, C. gonytrichii, Corollospora marina, C. parvula, C. ramulosa, Juncigena fruticosae, Melanospora simplex, Seimatosporium massarina, Sporoschisma daemonoropis, S. taitense, Torpedospora mangrovei, Xylaria penicilliopsis, and $X$. termiticola combs. nov.
Key words: Ascomycota nomenclature pleomorphic fungi protected lists taxonomy

Article info: Submitted: 26 April 2016; Accepted: 24 May 2016; Published: 8 June 2016.

Cㅇ 2016 International Mycological Association

You are free to share - to copy, distribute and transmit the work, under the following conditions:

Attribution: $\quad$ You must attribute the work in the manner specified by the author or licensor (but not in any way that suggests that they endorse you or your use of the work).

Non-commercial:

You must attribute the work in the manner specified by
You may not use this work for commercial purposes.

No derivative works: You may not alter, transform, or build upon this work.

For any reuse or distribution, you must make clear to others the license terms of this work, which can be found at http://creativecommons.org/licenses/by-nc-nd/3.0/legalcode. Any of the above conditions can be waived if you get permission from the copyright holder. Nothing in this license impairs or restricts the author's moral rights. 


\section{INTRODUCTION:}

The class Sordariomycetes is composed of three subclasses and about 21 orders including many genera with species that express themselves in both their sexual and asexual morphs. Based on the obsolete version of Article 59 of the outdated International Code of Botanical Nomenclature (McNeill et al. 2006), these morphs had previously been described in different genera resulting in more than one scientific name for a single fungal species. With the change to the International Code of Nomenclature for algae, fungi, and plants (ICN; McNeill et al. 2012), two or more names for different morphs of the same species are no longer allowed. Although determining which name to use generally follows the principle of priority of publication at the family, generic and species level, exceptions to this principle are allowed, especially in the case of economically important and widely used taxa.

In this paper generic names that appear to compete for use are reviewed to determine if their respective type species are congeneric using various resources including the USDA SMML Fungal Databases (http://nt.ars-grin.gov/ fungaldatabases/) and Wijayawardene et al. (2012). If so, then a number of factors are considered in deciding which generic name to recommend for use. These factors include the number of species in each competing genus, which correlates with the number of name changes that would be required, and how widely used are species in each genus as determined by reports and peer-reviewed publications. If these factors are about equal, then the generic name that has priority by date is recommended for use. For each set of competing generic names, these factors are discussed based on the literature. Finally, a draft of these recommendations was circulated widely amongst the community of mycologists interested in each major group of fungi to arrive at the proposals made here.

A synopsis of data concerning each genus is provided in Table 1 listing the generic names recommended for use and competing names, the type species for each genus and the current name for the type, and action required especially if the principle of priority will not be followed, i.e. the generic name must be protected. At present the ICN requires that names typified by sexual morphs should have priority unless protected, although it is proposed that this requirement be deleted in 2017 (Hawksworth 2015). Eventually all generic names proposed for protection will be evaluated by the Nomenclature Committee for Fungi (NCF), and formally accepted or not at the Nomenclature Section meeting of the next International Botanical Congress in 2017.

For several groups of fungi having pleomorphic genera, this process has been completed, i.e. Dothideomycetes (Rossman et al. 2015b), Erysiphales (Braun 2013), Eurotiales (Samson et al. 2014, Visagie et al. 2014), Leotiomycetes (Johnston et al. 2014), yeast fungi (Daniel et al. 2014), and some orders of Sordariomycetes including Diaporthales (Rossman et al. 2015a), Hypocreales (Rossman et al. 2013, Quandt et al. 2014), Magnaporthales (Zhang et al. 2016), and Microascales and Ophiostomatales (de Beer et al. 2013). This paper addresses the remaining orders of the class Sordariomycetes listed alphabetically by order as outlined in Maharachchikumbura et al. (2015): Amphisphaeriales,
Calosphaeriales, Chaetosphaeriales, Coniochaetales, Conioscyphales, Cordanales, Coronophorales, Glomerellales, Halosphaeriales, Melanosporales, Microascales, Phyllachorales, Pleurotheciales, Savoryellales, Sordariales, Togniniales, Torpedosporales, and Xylariales.

\section{RECOMMENDATIONS FOR GENERIC NAMES}

$(A)=$ a name typified by an asexual morph, and $(S)=$ a name typified by a sexual morph.

\section{Amphisphaeriales}

Use Dyrithiopsis L. Cai et al. 2003 (S) rather than Monochaetiopsis L. Cai et al. 2003 (A) The monotypic genera Dyrithiopsis, typified by $D$. lakefuxianensis, and Monochaetiopsis, typified by $M$. lakefuxiansis, were described as the sexual and asexual morph of the same species at the same time (Jeewon et al. 2003), thus they are synonyms and have equal priority. Because Dyrithiopsis has been cited more widely in the literature, we recommend Dyrithiopsis for use.

\section{Use Hyalotiopsis Punith. 1970 (A) rather than} Ellurema Nag Raj \& W.B. Kendr. 1985 (S)

When Punithalingam (1970) described the genus Hyalotiopsis, typified by $H$. subramanianii, he noted that the sexual morph was Massaria indica, the basionym of Ellurema indica, type of the monotypic Ellurema, thus Hyalotiopsis and Ellurema are synonyms. This history was recounted by Nag Raj \& Kendrick (1986) when they described Ellurema. A second species of Hyalotiopsis has been redisposed in Parahyalotiopsis as $P$. borassi (syn. Hyalotiopsis borassi) (Nag Raj 1976), thus both genera include only one species. Given their equal use, we follow priority and recommend Hyalotiopsis for use.

\section{Use Pestalotiopsis Steyaert 1949 (A) rather than Pestalosphaeria M.E. Barr 1975 (S)}

The well-known genus Pestalotiopsis, typified by $P$. guepinii, was established for many species of Pestalotia determined to be distinct from the type of Pestalotia, $P$. pezizoides. Barr (1975) described the genus Pestalosphaeria, typified by $P$. concentrica, for the sexual morph of Pestalotiopsis guepiniivar. macrotricha, both species on Rhododendron in southeastern North America. Thus, it appears that Pestalosphaeria is a synonym of Pestalotiopsis. Pestalotiopsis has been widely used and currently includes more than 200 names with two recent accounts of the genus (Maharachchikumbura et al. 2012, 2014). On the other hand, Pestalosphaeria includes 14 names, none of which are commonly used. Given the ubiquitous and widely reported species of Pestalotiopsis as well as the number of names in that genus and its priority, we recommend use of Pestalotiopsis.

\section{Use Seimatosporium Corda 1833 (A) rather than Discostroma Clem. 1909 (S)}

The generic names Discostroma and Seimatosporium have been applied to sexual and asexual morphs of the same species based on morphological studies (Brockmann 
1976, Nag Raj 1993). The type species of Discostroma, D. rehmii, is a younger synonym of $D$. massarina, and has an asexual morph referred to as Seimatosporium ribis-alpini while the type of Seimatosporium, S. rosae, has a sexual morph described as Discostroma rosae (Shoemaker 1964, Brockmann 1976, Nag Raj 1993). Although neither of the type species of Discostroma or Seimatosporium were included, Tanaka et al. (2011) used three species of Discostroma and sixteen species of Seimatosporium in their LSU tree to show that representatives of these genera form a monophyletic genus that should be regarded as Seimatosporium. Norphanphoun et al. (2015) added four more isolates of Seimatosporium including one for the type species, $S$. rosae, and also concluded that the genus was monophyletic. Host-specificity should be considered in studying the taxonomy of this genus. Given that Seimatosporium is the oldest name, has the greater number of species, and is more commonly used, this generic name is recommended for use.

New combination:

Seimatosporium massarina (Sacc.) Jaklitsch \& Voglmayr, comb. nov.

MycoBank MB817259

Basionym: Metasphaeria massarina Sacc., Atti Soc. VenetoTrent. Sci. Nat., Padova, Sér. 6 2: 22 (1884).

Synonyms: Discostroma massarina (Sacc.) Arx, Gen. Fungi Sporul. Cult., $2^{\text {nd }}$ edn. (Vaduz): 131 (1974).

Hendersonia ribis-alpini Fautrey, Revue Mycol., Toulouse 14: 171 (1892).

Seimatosporium ribis-alpini (Fautrey) Shoemaker \& E. Müll., Canad. J. Bot. 42: 403 (1964).

Curreya rehmii Schnabl, Ber. Bayer. Bot. Ges., Beih. 2: 66 (1892)

Discostroma rehmii (Schnabl) Clem., Gen. Fungi: 173 (1909).

Use Seiridium Nees 1816 (A) rather than Blogiascospora Shoemaker et al. 1966 (S)

According to Shoemaker et al. (1966) Seiridium marginatum, the type species of Seiridium, is the asexual morph of Blogiascospora marginata, type of the monotypic genus Blogiascospora, thus Seiridium and Blogioascopsora are synonyms as confirmed by Jaklitsch et al. (2016). Seiridium is the older generic name, has the greater number of species, and is the more widely used, therefore Seiridium is recommended for use.

One species of Seiridium, S. cupressi, cause of the widespread disease known as cypress canker, has previously been referred to as Lepteutypa cupressi. The type of Lepteutypa, L. fuckelii, is now placed in a distinct genus in the Amphisphaeriaceae (Jaklitsch et al. 2016), while the species previously regarded as $L$. cupressi belongs in Seiridium as $S$. cupressi in Sporocadaceae.

\section{Calosphaeriales}

Use Calosphaeria Tul. \& C. Tul. 1863 (S) rather than Calosphaeriophora Réblová et al. 2004 (A)
The genus Calosphaeria, typified by C. princeps, includes 114 names while an asexual morph of $C$. pulchella was described in the monotypic genus Calosphaeriophora as Ca. pulchella (Réblová et al. 2004). Calosphaeria pulchella is a saprobic fungus occurring on various woody plants and has been recently isolated from wood of sweet cherry trees showing canker symptoms (Trouillas et al. 2010a, Berbegal et al. 2014). If Calosphaeria princeps and C. pulchella are congeneric, then these generic names are synonyms as suggested by Réblová et al. (2015). Based on priority, the number of species in the genus, and its widespread use, the generic name Calosphaeria is recommended for use.

\section{Use Pleurostoma Tul. \& C. Tul. 1863 (S) rather} than Pleurostomophora Vijaykr. et al. 2004 (A) The genus Pleurostoma, typified by $P$. candollei, includes six names, two of which have been placed elsewhere. One species, $P$. ootheca, has an asexual morph described as Pleurostomophora ootheca, the type species of Pleurostomophora (Vijaykrishna et al. 2004). Réblová et al. (2015) explored the phylogeny of this group including one species of Pleurostoma and four species of Pleurostomophora, although the type species of Pleurostoma was not available. While both sexual species are lignicolous, the asexual species were isolated from woody plants, soil or sewage (Schol-Schwarz 1970). They were also identified as etiological agents of subcutaneous phaeohyphomycosis (Meyer et al. 1975, Hironaga et al. 1989), and one asexual species of Pleurostoma, P. ochraceum, is known to cause human eumycetoma (Mhmoud et al. 2012). Assuming that Pleurostoma candollei and $P$. ootheca are congeneric, these generic names are synonyms. Given that the name Pleurostoma has priority, has the greater number of species, and has been widely used, we recommend the use of Pleurostoma. Based on these conclusions and recent molecular data, the three exclusively asexual Pleurostomophora species were transferred to Pleurostoma by Réblová et al. (2015).

\section{Use Togniniella Réblová et al. 2004 (S) rather than Phaeocrella Réblová et al. 2004 (A)}

The monotypic genera Togniniella, typified by $T$. acerosa, and Phaeocrella, typified by $P$. acerosa, were described in the same article for the sexual and asexual morphs of the same species and thus are synonyms having equal priority (Réblová et al. 2004). Although an older epithet was discovered for $T$. acerosa (Réblová 2011), this was later rescinded (Réblová et al. 2015). We recommend the use of the generic name Togniniella.

\section{Chaetosphaeriales}

Use Chloridium Link 1809 (A) rather than Gonytrichum Nees \& T. Nees 1818 (A) or Melanopsammella Höhn.1920 (S)

The type species of Chloridium, C. viride as C. virescens, has long been known to be a synonym of Chaetosphaeria vermicularioides (syn. Melanopsammella vermicularioides), a species that is congeneric with $M$. inaequalis, the type of Melanopsammella (Réblová \& Winka 2000, Fernández et al. 
2006, Crous et al. 2012). The type species of Gonytrichum, $G$. caesium, is the asexual morph of $M$. inaequalis (Hughes 1951), thus Chloridium, Gonytrichum and Melanopsammella are synonyms. Over 60 names have been placed in Chloridium, the most well-known of these three generic names. Chloridium was monographed by Gams \& Holubová-Jechová (1976), however, many of these names have been removed to other genera. Gonytrichum includes over 20 species while Melanopsammella consists of five species, two of which already have names in Chloridium (Réblová et al. 1999, Réblová 2000). Melanopsammella has been distinguished from Chaetosphaeria by several authors (Réblová \& Winka 2000, Fernández \& Huhndorf 2005, Fernández et al. 2006, Crous et al. 2012). Given the widespread use of Chloridium and its priority, the generic name Chloridium is recommended for use.

New combinations:

Chloridium caesium (Nees) Réblová \& Seifert, comb. nov.

MycoBank MB816825

Basionym: Gonytrichum caesium Nees, Nova Acta Phys.Med. Acad. Caes. Leop.-Carol. Nat. Cur. 9: 244 (1818).

Synonyms: Eriosphaeria inaequalis Grove, J. Bot., Lond. 24: 132 (1886).

Melanopsammella inaequalis (Grove) Höhn., Ann. Mycol. 17: 121 (1920).

Chloridium chloroconium (W. Gams \& Hol.-Jech.) Réblová \& Seifert, comb. nov.

MycoBank MB816826

Basionym: Chaetosphaeria chloroconia W. Gams \& Hol.Jech., Stud. Mycol. 13: 86 (1976).

Synonyms: Melanopsammella chloroconia (W. Gams \& Hol.Jech.) Réblová et al., Sydowia 51: 65 (1999).

Gonytrichum chlamydosporium G.L. Barron \& G.C. Bhatt, Mycopath. Mycol. appl. 32: 126 (1967).

Because the name Chloridium chlamydosporium (J.F.H. Beyma) S. Hughes 1958 already exists, and refers to a different taxon, the next older epithet for this species is taken up and placed in Chloridium.

Chloridium gonytrichii (F.A. Fernández \& Huhndorf) Réblová \& Seifert, comb. nov.

MycoBank MB816827

Basionym: Melanopsammella gonytrichii F.A. Fernández \& Huhndorf, Fungal Diversity 18: 42 (2005).

Crous et al. (2012) showed that this species is closely related to Chloridium virescens as Melanopsammella vermicularioides.

\section{Use Menispora Pers. (A) 1822 rather than Zignoëlla Sacc. 1878 (S)}

The genus Menispora is typified by M. glauca, which has a sexual morph referred to as Chaetosphaeria glauca (Holubová-Jechová 1973a), which is a synonym of the earlier name Zignoëlla ovoidea. The type of Zignoëlla is $Z$. pulviscula,which has an asexual morph known as Menispora caesia (Booth 1957, Constantinescu et al. 1995). Fernández et al. (2006) demonstrated that Zignoëlla is distinct from Chaetosphaeria based on $C$. innumera and that Z. pulviscula and Z. ovoidea are congeneric, thus Menispora and Zignoëlla are synonyms. Like Chaetosphaeria, Zignoëlla has been used as a repository for species that have a similar morphology, namely black non-stromatic ascomata with a papilla and hyaline, septate ascospores, but are phylogenetically diverse. Given the lack of characterization of Zignoëlla, the greater use of Menispora, and following the principle of priority, Menispora is recommended for use.

\section{Use Menisporopsis S. Hughes 1952 (A) rather than Menisporopascus Matsush. 2003 (S)}

The monotype species of Menisporopascus, M. kobensis, was described for the asexual morph Menisporopsis kobensis. Because M. kobensis is congeneric with the type species of Menisporopsis, M. theobromae, as indicated by Rodrigues de Cruz et al. (2014), Menisporopsis and Menisporopascus are synonyms. Menisporopsis includes 10 names, is widely known, and has priority, therefore, the use of Menisporopsis is recommended.

Use Sporoschisma Berk. \& Broome 1847 (A) rather than Melanochaeta E. Müll. et al. 1969 (S)

The genus Sporoschisma, typified by S. mirabile, is considered the asexual morph of Melanochaeta aotearoae, while the type of Melanochaeta, M. hemipsila, is the sexual morph of $S$. saccardoi, now considered a synonym of $S$. hemipsila (Sivichai et al. 2000, Zelski et al. 2014a). Sporoschisma mirabile and $S$. hemipsila were shown to be congeneric (Fernández et al. 2006), thus Sporoschisma and Melanochaeta are synonyms. Of the five species in Melanochaeta, four have Sporoschisma asexual morphs (Sivichai et al. 2000, Mugambi \& Huhndorf 2008). Sporoschisma includes 23 names, some of which have been placed elsewhere. If Melanochaeta were used, many name changes would be required. Based on priority and fewer number of name changes, we follow Zelski et al. (2014a) and recommend the use of Sporoschisma for this genus.

New combinations:

Sporoschisma daemonoropis (J. Fröhl. \& K.D. Hyde) A.N. Mill., comb. nov.

MycoBank MB816828

Basionym: Melanochaeta daemonoropis J. Fröhl. \& K.D. Hyde, Palm Microfungi: 235 (2000).

Sporoschisma taitense (Mugambi \& Huhndorf) A.N. Mill., comb. nov.

MycoBank MB816829

Basionym: Melanochaeta taitensis Mugambi \& Huhndorf, Sydowia 60: 263 (2008).

A Sporoschisma asexual morph was noted to occur with this type specimen. 


\section{Use Stanjehughesia Subram. 1992 (A) rather than Umbinosphaeria Réblová 1999 (S)}

Stanjehughesia hormiscioides, type of Stanjehughesia, was established with cultivation techniques as an asexual morph of Umbrinosphaeria caesariata, the monotype species of Umbrinosphaeria (Réblová 1999), therefore Stanjehughesia and Umbrinosphaeria are synonyms. In exploring species of Sporidesmium, Shenoy et al. (2006) demonstrated the polyphyletic nature of Stanjehughesia; however, 15 species have been described in that genus and the name is well-known. Given its priority, we recommend the use of Stanjehughesia.

\section{Coniochaetales}

\section{Use Coniochaeta (Sacc.) Cooke 1887 (S) rather than Lecythophora Nannf. 1934 (A)}

The genus Coniochaeta, typified by C. ligniaria, was shown to be congeneric with Lecythophora, typified by L. lignicola (Weber et al. 2002, Damm et al. 2010, Khan et al. 2013 , Perdomo et al. 2013). Coniochaeta is a well-known genus with almost 100 names while Lecythophora includes nine names, two of which are linked to species of Coniochaeta. These fungi are known as endophytes, pathogens of woody trees, saprobes in terrestrial and freshwater habitats (Raja et al. 2012) and, to a lesser degree, human pathogens (Damm et al. 2010). Both Khan et al. (2013) and Perdomo et al. (2013) include species of Lecythophora in a clade with the type species of Coniochaeta. Given the number of species, its widespread use, following the principle of priority, and in agreement with Khan et al. (2013), Coniochaeta is recommended for use.

\section{Conioscyphales}

\section{Use Conioscypha Höhn. 1904 (A) rather than Conioscyphascus Réblová \& Seifert 2004 (S)}

The genus Conioscypha, with $C$. lignicola as type species, includes 13 species from freshwater and terrestrial habitats. The genus Conioscyphascus, typified by $\mathrm{Ca}$. varius, was originally established for fungi with Conioscypha asexual morphs (Réblová \& Seifert 2004a). The two sexual species, Ca. gracilis with C. gracilis as its asexual morph and $\mathrm{Ca}$. varius with $C$. varia, were recently placed in Conioscypha (Zelski et al. 2014b, Réblová et al. 2016). Although C. lignicola and 10 other species of Conioscypha are known only in their asexual morph, using DNA sequence data and cultivation studies, the link between sexual and asexual morphs has been experimentally proven for $C$. peruviana (Zelski et al. 2014b) and C. varia (Réblová \& Seifert 2004a). Such a link has not yet been confirmed for the third species known to have a sexual morph, $C$. gracilis, however, conidia were observed on the substratum near ascomata (Réblová \& Seifert 2004a, Zelski et al. 2014b). The molecular data clearly show that Conioscypha and Conioscyphascus are congeneric (Réblová \& Seifert 2004a). Based on priority and the greater number of species, the name Conioscypha is recommended for use.

\section{Cordanales}

Use Cordana Preuss 1851 (A) rather than Pseudobotrytis Krzemien. \& Badura 1954 (A) or Porosphaerella E. Müll. \& Samuels 1982 (S)

The type species of Cordana, C. pauciseptata, was linked to a sexual morph described as Porosphaerella cordanophora, type of Porosphaerella (Müller \& Samuels 1982), thus these generic names are synonyms. Cordana is a well-known asexual genus that includes 22 names while three species have been placed in Porosphaerella. Réblová and Seifert (2007) showed that $P$. borinquinensis and $P$. cordanophora are closely related despite the fact that $P$. borinquinensis has an asexual morph regarded as Pseudobotrytis terrestris which Hernández-Restrepo et al. (2014) recognized as Cordana terrestris including Porosphaerella borinquinensis as a synonym. They also considered the type species of Pseudobotrytis, P. fusca, to be a synonym of $C$. terrestris, thus this generic name with four species is also a synonym of Cordana. Given its priority, fewer number of name changes required, and widespread use, we recommend the use of Cordana rather than Pseudobotrytis or Porosphaerella.

\section{Coronophorales}

Protect Chaetosphaerella E. Müll. \& C. Booth 1972 (S) over Oedemium Link 1824 (A) and rather than Veramycina Subram. 1995 (A)

The genus Chaetosphaerella, typified by C. phaeostroma, has an asexual morph regarded as Oedemium minus (Booth 1958, Réblová 1999). The type species of Oedemium, $O$. atrum as $O$. didymium, is the asexual morph of Chaetosphaerella fusca (Ellis 1971). These two species of Chaetosphaerella were shown to be congeneric (Mugambi \& Huhndorf 2010), thus Chaetosphaerella and Oedemium are synonyms. Veramycina elegans, the monotype species of Veramycina, was regarded as a later name for the asexual morph of C. phaeostroma (Réblová 1999), thus this generic name is also a synonym of Chaetosphaerella. Because Veramycina has been rarely used, that name is not a contender for use, however, the decision of whether to use Oedemium or Chaetospharella is more difficult. The genus Oedemium was clarified and monographed including two species by Hughes \& Hennebert (1963) both of which have been linked with Chaetosphaerella. Although more species have been described in Oedemium, some have been placed elsewhere and others remain obscure. Chaetosphaerella has been placed phylogenetically in Chaetosphaerellaceae, Coronophorales (Mugambi \& Huhndorf 2010). In the past decade Chaetosphaerella appears in the literature much more frequently than Oedemium, thus we recommend Chaetosphaerella for protection.

\section{Glomerellales}

\section{Use Colletotrichum Corda 1837 (A) rather than Glomerella Spauld. \& Schrenk 1903 (S)}

The genus Colletotrichum, typified by $C$. lineola, is a large genus with 817 epithets (Index Fungorum 2016), many of which are considered plant pathogens. The number of 
accepted species has varied over the decades with most species previously considered to be host-specific. Based on von Arx (1957) in which several hundred names were placed in synonymy with $C$. gloeosporioides, the number of species in Colletotrichum decreased to 11. Sutton (1980) included about 22 species in Colletotrichum for which he provided a key. With the use of molecular sequence data, the number of recognized species has increased with some species determined to be host-specific while others have a broad host range (Rojas et al. 2010, Damm et al. 2009, 2012, Weir et al. 2012). The type species, Colletotrichum lineola, had long been considered to be a synonym of $C$. dematium but was recently recognized as a distinct species in the $C$. dematium species complex (Damm et al. 2009, Cannon et al. 2012). Meanwhile, the sexual morphs of Colletotrichum were placed in the genus Glomerella, typified by $G$. cingulata, which has been considered the sexual morph of $C$. gloeosporioides. Recently this relationship has been questioned with $C$. gloeosporioides and $G$. cingulata regarded as distinct species in the $C$. gloeosporioides species complex (Weir et al. 2012). Over 100 names have been described in Glomerella, many of which have names in Colletotrichum. Although considered different species, there is no question that Colletotrichum and Glomerella represent the same genus.

Use of Colletotrichum over Glomerella is recommended for use for several reasons. Species of Colletotrichum are mainly associated with plants as endophytes and pathogens and have been thoroughly studied. In contrast, their sexual morphs regarded as Glomerella tend to occur on dead plant material and are less frequently encountered (Cannon et al. 2012, Maharachchikumbura et al. 2015). Colletotrichum is the older generic name and is well established in the plant pathological and plant breeder literature (Cannon et al. 2012). Preference has been given to Colletotrichum by several groups working on this genus (Cannon et al. 2012, Maharachchikumbura et al. 2015) based on its widespread use, greater number of names, and priority.

\section{Use Cylindrotrichum Bonord. 1851 (A) rather than Reticulascus Réblová \& W. Gams 2011 (S)}

The type species of Cylindrotrichum, C. oligospermum, was shown to represent the asexual morph of Chaetosphaeria tulasneorum, the type species of Reticulascus (Réblová \& Gams 1999, Réblová et al. 2011a), thus the generic names Cylindrotrichum and Reticulascus are synonyms. Cylindrotrichum includes 23 names (Rambelli \& Onofri 1987) while Reticulascus includes only two names. Between these two generic names, Cylindrotrichum is the most widely known. Given its widespread use, priority, and greater number of names, we recommend the use of Cylindrotrichum rather than Reticulascus.

\section{Use Monilochaetes Halst. ex Harter 1916 (A)} rather than Australiasca Sivan. \& Alcorn 2002 (S)

The type species of Monilochaetes, M. infuscans, was shown to be congeneric with Australiasca queenslandica, the type species of Australiasca (Réblová et al. 2011a). The two species described in Australiasca have names in Monilochaetes, thus, if the older name Monilochaetes is used, no name changes are required. This generic name includes six species and has priority, thus Monilochaetes is recommended for use.

\section{Use Plectosphaerella Kleb. 1929 (S) rather than Plectosporium M.E. Palm et al. 1995 (A)}

The genus Plectosporium, typified by $P$. tabacinum, was established for the asexual morph of species of Plectosphaerella of which the type species, $P$. cucumeris, is the name applied to the sexual morph of Plectosporium tabacinum (Palm et al. 1995), thus Plectosphaerella and Plectosporium are synonyms. Plectosphaerella cucumerinum is known as the cause of fruit and collar rot, and collapse of several crops including melons (Carlucci et al. 2012). Plectosphaerella includes 14 names while four species have been placed in Plectosporium. Carlucci et al. (2012) provided a molecular account of Plectosphaerella in the Plectosphaerellaceae and transferred species of Plectosporium to Plectosphaerella. Given its priority, greater number of names, economic importance, and recent account of the genus, the use of Plectosphaerella is recommended.

\section{Use Sporoschismopsis Hol.-Jech. \& Hennebert} 1972 (A) rather than Porosphaerellopsis Samuels \& E. Müll. 1982 (S)

The generic name Sporoschismopsis was introduced by Holubová-Jechová \& Hennebert (1972) with S. moravica as type species and it now includes eight names (HolubováJechová 1973b). The generic name Porosphaerellopsis, typified by $P$. sporoschismophora (Samuels \& Müller 1978, Müller \& Samuels 1982), was established for the sexual morphs of Sporoschismopsis. Porosphaerellopsis sporoschismophora was transferred to Sporoschismopsis (Réblová 2014) while a second species, P. bipolaris described by Ranghoo et al. (2001), was excluded from the genus. Another sexual morph was experimentally proven for $S$. angustata (Réblová 2014). Based on DNA sequence data, the two asexual morphs, S. angustata and S. sporoschismophora, form a strongly supported monophyletic clade in the Reticulascaceae, Glomerellales. Given that S. angustata, S. moravica, and S. sporoschismophora are congeneric, the generic names Sporoschismopsis and Porosphaerellopsis are synonyms. Based on priority and the greater number of species, Sporoschismopsis is recommended for use.

\section{Halosphaeriales}

Use Corollospora Werderm. 1922 (S) rather than Varicosporina Meyers \& Kohlm. 1965 (A) and Halosigmoidea Nakagiri et al. 2009 (A)

Although the type species of Corollospora, C. maritima, does not appear to have an asexual morph in Varicosporina, a number of species of Corollospora are linked to varicosporinalike asexual morphs. Abdel-Wahab et al. (2009) showed that the type of Varicosporina, V. ramulosa, groups within Corollospora, thus Corollospora and Varicosporina are synonyms. The type species of Halosigmoidea, $\mathrm{H}$. luteola as Sigmoidea luteola, was shown by culture techniques to be the asexual morph of Corollospora luteola (Nakagiri \& Tokura, 1982). Jones et al. (2009) demonstrated that the three marine species 
recognized in Halosigmoidea grouped with Corollospora, thus Halosigmoidea is also a synonym of Corollospora. Over 20 species are included in Corollospora while only three names have been described in Varicosporina, two of which have names in Corollospora, and only three names were included in Halosigmoidea. Given the number of names, widespread use, and priority, we recommend the use of Corollospora.

New combinations:

Corollospora marina (Haythorn \& E.B.G. Jones) E.B.G. Jones, K.L. Pang \& Abdel-Wahab, comb. nov.

MycoBank MB816830

Basionym: Sigmoidea marina Haythorn \& E.B.G. Jones, Trans. Brit. Mycol. Soc. 74: 620 (1980).

Synonym: Halosigmoidea marina (Haythorn \& E.B.G. Jones) Nakagiri et al., Bot. Mar. 52: 355 (2009).

Corollospora parvula (Zuccaro et al.) E.B.G. Jones, K.L. Pang \& Abdel-Wahab, comb. nov.

MycoBank MB816831

Basionym: Halosigmoidea parvula Zuccaro et al., Bot. Mar. 52: 355 (2009).

Corollospora ramulosa (Meyers \& Kohlm.) E.B.G. Jones \& Abdel-Wahab, comb. nov.

MycoBank MB816832

Basionym: Varicosporina ramulosa Meyers \& Kohlm., Canad. J. Bot. 43: 916 (1965).

\section{Melanosporales}

\section{Use Melanospora Corda 1836 (S) rather than Gonatobotrys Corda 1839 (A)}

The type species of Melanospora, M. zamiae, has been shown to be congeneric with $M$. damnosa (Cannon \& Hawksworth 1982), of which the type species of Gonatobotrys, G. simplex, is considered a synonym (Vakili 1989). Given the widespread use of Melanospora, its priority, and the 120 names in Melanospora while Gonatobotrys includes only 32 names, Melanospora is recommended for use.

New combination:

Melanospora simplex (Corda) D. Hawksw., comb. nov.

MycoBank MB816833

Basionym: Gonatobotrys simplex Corda, Prachtflora: 9 (1839).

Synonyms: Sphaeroderma damnosum Sacc. \& Berl., Riv. Patol. Veg. 4: 56 (1896) [“1895”].

Melanospora damnosa (Sacc.) Lindau, Nat. Pflanzenfam. 1 $\left(1^{*}\right): 353$ (1897).

\section{Microascales}

Use Knoxdaviesia M.J. Wingf. et al. 1988 (A) rather than Gondwanamyces G.J. Marais \& M.J. Wingf. 1998 (S)
Knoxdaviesia proteae, type of the genus Knoxdaviesia, was described as the asexual morph of Ceratocystiopsis proteae, a species that was later placed in the genus Gondwanamyces as the type species, thus Knoxdaviesia and Gondwanamyces are synonyms. Both generic names have been used about equally. In agreement with de Beer et al. (2013), the use of the oldest name, Knoxdaviesia, is recommended.

\section{Use Sphaeronaemella P. Karst. 1884 (S) rather} than Gabarnaudia Samson \& W. Gams 1974 (A) The type species of Sphaeronaemella, $S$. helvellae, is congeneric with the type species of Gabarnaudia, G. betae, described as the asexual morph of $S$. fimicola (Samson 1974). Confirmed by molecular data (Hausner \& Reid 2004), these generic names are synonyms. Five species of Gabarnaudia have been placed in Sphaeronaemella (De Beer et al. 2013), a genus with 30 species. Sphaeronaemella is most commonly used and has priority, thus we recommend the use of Sphaeronaemella.

\section{Phyllachorales}

Use Diachora Müll. Arg. 1893 (S) rather than Diachorella Höhn. 1918 (A)

The generic names Diachora, typified by $D$. onobrychidis, and Diachorella, typified by $D$. onobrychidis, are apparently based on the same type specimen, thus these names are synonyms. Diachora is considered a name for the sexual morph while Diachorella represents the asexual morph. Both generic names include less than ten species. Müller (1986) and Cannon (1991) reviewed species in these genera including the type species. Because Diachora is more widely known and has priority, we recommend that name for use.

Use Ophiodothella (Henn.) Höhn. 1904 (S) rather than Acerviclypeata Hanlin 1990 (A)

The genus Ophiodothella, typified by $O$. atromaculans, now includes 26 species, which are obligate parasites of subtropical and tropical plants (Hanlin et al. 1992). An asexual morph of $O$. vaccinii, now $O$. angustissima, cause of flyspeck leafspot of Vaccinium arboretum in the southeastern United States, was described as the monotype species of Acerviclypeatus, A. poriformans (Hanlin 1990), thus Ophiodothella and Acerviclypeatus are synonyms. Not much is known about $O$. atromaculans but this species appears to be congeneric with $O$. angustissima (Hanlin \& Gonzáles 2013). Given the number of species and priority, we recommend the use of Ophiodothella.

Use Polystigma DC 1815 (S) rather than Polystigmina Sacc. 1884 (A) and Rhodoseptoria Naumov 1913 (A)

The generic names Polystigma, typified by P. rubrum, and Polystigmina, typified by $P$. rubrum, are based on the same basionym of their respective type species and, therefore, are synonyms for the sexual and asexual morphs. Cannon (1996) monographed Polystigma including five species on Prunus among others. He also noted that the type species of the monotypic Rhodoseptoria was a synonym of Polystigma 
rubra, thus that generic name is also a synonym of Polystigma. Several species of Polystigma cause diseases such as red blotch of almonds caused by $P$. amygdalinum and red leaf spot of plum caused by P. rubrum (Habibi et al. 2015). All but two of the seven taxa placed in Polystigmina are synonyms of Polystigma rubra while Polystigma includes over 50 species. Given the greater number of species, its widespread use, economic importance, and priority, we recommend the use of Polystigma.

\section{Use Pseudothiella Petr. 1928 (S) rather than Pseudothiopsella Petr. 1928 (A)}

The monotypic generic names Pseudothiella, typified by $P$. hirtellae, and Pseudothiopsella, typified by $P$. hirtellae, were described at the same time for sexual and asexual morphs of the same species, thus they are synonyms with equal priority. Pseudothiella has been used slightly more often than Pseudothiopsella (Furlanetto \& Dianese 1998), therefore we recommend use of Pseudothiella.

\section{Pleurotheciales}

Use Pleurothecium Höhn. 1919 (A) rather than Carpoligna F.A. Fernández \& Huhndorf 1999 (S)

The genus Pleurothecium is typified by $P$. recurvatum. A sexual morph is known for $P$. recurvatum for which the monotypic generic name Carpoligna, typified by $C$. pleurothecii, was introduced (Fernández et al. 1999). Of the eight species assigned to the genus Pleurothecium, only three have DNA sequence data. Pleurothecium recurvatum and $P$. semifecundum form a strongly supported monophyletic clade in the Pleurotheciales and represent the core of the genus (Réblová et al. 2016), while P. obovoideum (Arzanlou et al. 2007) is nested in the same order but within another clade. Given its priority and greater number of species, Pleurothecium is recommended for use.

\section{Savoryellales}

Use Canalisporium Nawawi \& Kuthub. 1989 (A) rather than Ascothailandia Sri-indr. et al. 2010 (S)

The genus Canalisporium, typified by $C$. caribense, includes 12 species (Nawawi \& Kuthubutheen 1989). A sexual morph was described for $C$. grenadoideum and linked to the monotypic genus Ascothailandia, typified by $A$. grenadoidea (Sri-indrasutdhi et al. 2010). The link between sexual and asexual morphs of this species was confirmed experimentally in axenic culture. Six species of Canalisporium, including the type species, were the subject of phylogenetic analysis based on DNA sequence data of three nuclear loci by Sriindrasutdhi et al. (2010) who confirmed that Ascothailandia and Canalisporium are congeneric. Based on priority and the greater number of species, the generic name Canalisporium is recommended for use.

\section{Sordariales}

Use Chaetomium Kunze 1817 (S) rather than Trichocladium Harz 1871 (A), Botryotrichum Sacc. \& Marchal 1885 (A), or Humicola Traaen 1914 (A)

Chaetomium, typified by C. globosum, is a well-known genus of cellulose-decomposing fungi some of which cause diseases of humans. The sexual morph of Botryotrichum piluliferum, type of the asexual genus Botryotrichum, was described as Chaetomium piluliferum (Daniels 1961). Later this species was confirmed to be congeneric with C. globosum (Untereiner et al. 2001, Nonaka et al. 2012), thus Chaetomium and Botryotrichum are synonyms. Although sexual states have not been discovered for the type of Humicola, $H$. fuscoatra or related species such as the common $H$. grisea, nuc28S rDNA sequences place these species within the present concept of Chaetomium. The type of Trichocladium, T. asperum, also lacks a sexual morph and occurs in the same clade (Hambleton et al. 2005). Over 500 names have been described in Chaetomium. Botryotrichum currently includes eight species. Humicola and Trichocladium each include about 20 species, but both are phylogenetically heterogeneous and most species belong to different clades. Given its extensive use and economic importance, its priority, and the greater number of species, we recommend the use of Chaetomium.

\section{Use Lasiosphaeris Clem. 1909 (S) rather than} Lasiadelphia Réblová \& W. Gams 2011 (A)

The genus Lasiosphaeris was described by Clements (1909) with $L$. hispida as its type species. The name was reestablished by Miller \& Huhndorf (2004) for species segregated from Lasiosphaeria based on nuc28S rDNA sequences. Two species were accepted in the genus, $L$. hispida and L. hirsuta. Gams \& Holubová-Jechová (1976) introduced Phialophora sect. Catenulatae, typified by the dematiaceous species Phialophora lasiosphaeriae, the asexual morph experimentally proven for $L$. hispida (as L. hirsuta, Gams \& Holubová-Jechová 1976, Gams 2000). Réblová et al. (2011b) desribed the generic name Lasiadelphia with $L$. lasiosphaeriae as the type species for the asexual morph of Lasiosphaeris hispida. Therefore, the type species of Lasiosphaeris and Lasiadelphia are morphs of the same species and the generic names are synonyms. Based on priority and the greater number of species, the generic name Lasiosphaeris should be used.

Use Mammaria Rabenh. 1854 (A) rather than Pseudocercophora Subram. \& Sekar 1986 (S)

The genus Mammaria, typified by M. echinobotryoides, includes two names while the monotypic genus Pseudocercophora, typified by $P$. ingoldii, was described for the sexual morph of $M$. echinobotryoides, thus these generic names are synonyms. If the principle of priority is followed, no names changes are required, thus, the use of Mammaria is recommended.

Use Neurospora Shear \& B.O. Dodge 1927 (S) rather than Chrysonilia Arx 1981 (A)

The genus Neurospora, typified by $N$. sitophila, includes the well-known model organism, $N$. crassa. The asexual 
morph of the type species was described in Chrysonilia with C. sitophila as the type species. There is no question that Neurospora and Chrysonilia are generic synonyms (von Arx 1981). At present Neurospora includes 57 names while only three names have been placed in Chrysonilia, all of which also have names in Neurospora. Given its priority, the number of species, and its widespread use, it is recommended that Neurospora be used rather than Chrysonilia.

Use Stromatographium Henn. 1907 (A) rather than Fluviostroma Samuels \& E. Müll. 1980 (S)

The genus Stromatographium, typified by S. stromaticum, is the asexual state of Fluviostroma wrightii, monotype species of Fluviostroma (Samuels \& Müller 1980). Seifert (1987) clarified the confusion between Stromatographium and Stromatostilbella and showed that the asexual morph of $F$. wrightii belongs in Stromatographium. Given its greater use and priority, we recommend the use of Stromatographium.

\section{Togniniales}

Protect Phaeoacremonium W. Gams 1996 (A) over Togninia Berl. 1900 (S) and Romellia Berl. 1900 (S)

The genus Phaeoacremonium was established for $P$. parasiticum, first described causing phaeohyphomycosis in humans, but also causing wilts in tropical trees and an economically important disease of grapevine known as esca disease (Hawksworth et al. 1976, Crous et al. 1996). Once this genus was described, a number of species were discovered and placed in Phaeoacremonium. Based on phylogenetic analysis and mating studies, sexual morphs were found for these species in Togninia, formerly attributed to Calosphaeriales (Mostert et al. 2003). Species of Phaeoacremonium are known as vascular plant pathogens such as esca and Petri disease of grapevine as well as human pathogens. Two monographic accounts of Phaeoacremonium have been published (Mostert et al. 2006, Réblová et al. 2015). Gramaje et al. (2015) formally proposed to protect the name Phaeoacremonium against Togninia because although Togninia has 26 epithets, half have not been reported since their description, and only nine species have been experimentally linked with Phaeoacremonium. Phaeoacremonium includes 46 species of which all are known from culture and their DNA data are available. Also Phaeoacremonium is favoured by plant pathologists and medical mycologists and is well established in the literature. All required new combinations were made in Gramaje et al. (2015). The type species of Romellia, $R$. vibratilis, was sequenced and placed in Togninia by Réblová \& Mostert (2007) and recently moved to Phaeoacremonium by Gramaje et al. (2015). Three of the four species of Romellia have since been placed elsewhere. Thus, because it is widely used and has the greatest number of species, we recommend the protection of Phaeoacremonium over Togninia and Romellia.

\section{Torpedosporales}

Use Juncigena Kohlm. et al. 1997 (S) rather than Moheitospora Abdel-Wahab et al. 2010 (A)

The monotypic genus Juncigena is typified by $\mathrm{J}$. adarca for which an asexual morph was described as Cirrenalia adarca (Kohlmeyer et al. 1997). Later the asexual species was placed in the genus Moheitospora as $M$. adarca along with the type species, M. fruticosae (Abdel-Wahab et al. 2010), thus Juncigena and Moheitospora are synonyms. Although one name change would be required, Juncigena has priority and has greater use in the literature, thus it is recommended that Juncigena be used. Schoch et al. (2007) showed that this genus belongs in Hypocreomycetidae and later Jones et al. (2015) placed it in Juncigenaceae, Torpedosporales.

\section{New combination:}

Juncigena fruticosae (Abdel-Wahab et al.) A.N. Mill. \& Shearer, comb. nov.

MycoBank MB816834

Basionym: Moheitospora fruticosae Abdel-Wahab et al., Mycol. Progr. 9: 551 (2010).

\section{Use Torpedospora Meyers 1957 (S) rather than} Glomerulispora Abdel-Wahab \& Nagah. 2010 (A)

The monotype species of Glomerulispora, G. mangrovei, groups with the two species of Torpedospora such that these generic names are considered synonyms (AbdelWahab et al. 2010, Jones et al. 2015). These species are marine fungi found on driftwood throughout the world. Given the widespread use of Torpedospora and its priority, use of Torpedospora is recommended.

New combination:

Torpedospora mangrovei (Abdel-Wahab \& Nagah.) E.B.G. Jones \& Abdel-Wahab, comb. nov.

MycoBank MB816835

Basionym: Glomerulispora mangrovei Abdel-Wahab \& Nagah., Mycol. Progr. 9: 553 (2010).

\section{Xylariales}

Use Arthrinium Kunze 1817 (A) rather than Apiospora Sacc. 1875 (S), Pteroconium Sacc. ex Grove 1914 (A), and Scyphospora L.A. Kantsch 1928 (A)

Species in the genus Arthrinium are widespread and commonly encountered as saprobes and secondary invaders especially on monocotyledonous plants. The common species, $A$. arundinis, is the name typified by the sexual morph of the type species of Apiospora, A. montagnei (Müller \& Arx 1962). Less is known about the type species of Arthrinium, A. caricicola, but this species is assumed to be congeneric with $A$. arundinis (Crous \& Groenewald 2013), although they were unable to find material to include in their molecular phylogeny. Crous \& Groenewald (2013) also showed that Pteroconium asteroides, type of Pteroconium, 
is a synonym of Arthrinium. Samuels et al. (1981) suggested that Scyphospora phyllostachydis was the asexual morph of Apiospora tintinnabula, now Arthrinium hysterinum, thus Scyphospora is a synonym of Arthrinium. In agreement with both Crous \& Groenewald (2013) and Senanayake et al. (2015), Arthrinium has priority and is the most widely used of these generic names, thus use of Arthrinium is recommended.

Although Hughes (1958) followed by Ellis (1965), Samuels et al. (1981) and Crous \& Groenewald (2013) suggested that Cordella is a synonym of Arthrinium, this is based on the assumption that $C$. coniosporioides is the type species. Cordella was described with two species without indicating a type. Clements \& Shear (1931) were the first to select a type species for Cordella and they list $C$. spinulosa, a species that Hughes (1958) placed in Melanographium, thus Cordella is not a synonym of Arthrinium.

Based on the molecular sequence data provided by Crous \& Groenewald (2013), Apiospora sinensis is placed in Arthrinium.

\section{New combination:}

Arthrinium sinense (K.D. Hyde et al.) Crous \& J.Z. Groenew., comb. nov.

MycoBank MB816836

Basionym: Apiospora sinensis K.D. Hyde et al., Sydowia 50: 27 (1998).

In addition a nomenclator is provided for Arthrinium hysterinum because of confusion about the correct name for this species and its numerous synonyms. Previously recognized in Apiospora by Tang et al. (2007), Kirk (1986) and Sivanesan (1983), Crous \& Groenewald (2013) and Senanayake et al. (2015) included Apiospora bambusae, $A$. setosa and $A$. tintinnabula as synonyms within the genus Arthrinium. The correct name for this species is Arthrinium hysterinum with the synonyms listed below:

Arthrinium hysterinum (Sacc.) P.M. Kirk, Trans. Brit. Mycol. Soc. 86: 409 (1986).

Basionym: Melanconium hysterinum Sacc., Bolm Soc. broteriana, Coimbra, sér. 111: 21 (1893).

Synonyms: Scyphospora hysterina (Sacc.) Sivan., Trans. Brit. Mycol. Soc. 81: 331 (1983).

Melanconium bambusae Turconi, Atti Ist. bot. R. Univ. Pavia, sér.2 16: 251 (1916).

Scirrhia bambusae Turconi, Atti lst. bot. R. Univ. Pavia, sér. 2 16: 531 (1916).

Scirrhodothis bambusae (Turconi) Trotter, in Saccardo, Syll. Fung. 24: 611 (1926).

Placostroma bambusae (Turconi) R. Sprague, Diseases Cereals Grasses N. Amer: 121 (1950).

Apiospora bambusae (Turconi) Sivan., Trans. Brit. Mycol. Soc. 81: 331 (1983).

Scyphospora phyllostachydis L.A. Kantsch., Bolêz. Rast. 17: 88 (1928).

Cordella johnstonii M.B. Ellis, Mycol. Pap. 103: 31 (1965).

Apiospora setosa Samuels et al., New Zealand J. Bot. 19: 142 (1981).
Apiospora tintinnabula Samuels et al., New Zealand J. Bot. 19: 142 (1981).

Use Collodiscula I. Hino \& Katum. 1955 (S) rather than Acanthodochium Samuels et al. 1987 (A)

The genus Collodiscula, typified by $C$. japonica, was linked to Acanthodochium collodisculae, type of Acanthodochium, by Samuels et al. (1987), who considered these names morphs of the same species, thus these generic names are synonyms. Three species have been added to Collodiscula ( $\mathrm{Li}$ et al. 2015a, b). Given that this generic name has priority and includes four species, the use of Collodiscula is recommended.

Use Daldinia Ces. \& De Not. 1863 (S) rather than Annellosporium M.L. Davey 2010 (A) or Versiomyces Whalley \& Watling 1989 (S)

The genus Daldinia, typified by $D$. concentrica, has recently been monographed by Stadler et al. (2014). They showed that the monotype species of Annellosporium, A. nemorosa, belongs in Daldinia as $D$. nemorosa, thus Daldinia and Annellosporium are synonyms. They also showed that the monotype species of Versiomyces, $V$. cahuchucosus, belongs in Daldinia as $D$. cahuchucosa, thus Versiomyces is a synonym of Daldinia. Daldinia is a well-known genus with many species and has priority, thus it is recommended for use.

\section{Protect Diatrype Fr. 1849 (S) over Libertella Desm. 1830 (A)}

The genus Diatrype, typified by $D$. disciformis, includes over 500 names (Index Fungorum 2016), some of which cause canker diseases of hardwoods such as $D$. stigma associated with diseased grapevines (Rolshausen et al. 2006). Libertella betulina, type of the genus Libertella, is known to be the asexual morph of Diatrype stigma (Grove 1937, Kutorga et al. 2006) and $D$. disciformis has an asexual morph described as $L$. disciformis. Trouillas et al. (2010b) showed that $D$. disciformis and $D$. stigma are congeneric, thus Diatrype and Libertella are synonyms. Because Diatrype is widely known, has a greater number of species, and includes important plant pathogenic fungi, Diatrype is recommended for protection over Libertella.

\section{Use Hypocreodendron Henn. 1897 (A) rather than Discoxylaria J.C. Lindq. \& J.E. Wright 1964 (S)}

Hypocreodendron is a monotypic genus based upon $H$. sanguineum for which Lindqvist \& Wright (1964) introduced the monotypic genus Discoxylaria, typified by $D$. myrmecophila, as the sexual morph. Rogers et al. (1995) observed a specimen of $D$. myrmecophila that bore both conidial and mature perithecial morphs. They compared their collection with the holotype specimen and obtained the conidial morph in culture initiated from ascospores to demonstrate that these were alternate morphs of the same species. Thus, Hypocreodendron and Discoxylaria are synonyms. In agreement with Stadler et al. (2013), Maharachchikumbura et al. (2015), and priority, we recommend the use of Hypocreodendron. 


\section{Use Hypoxylon Bull. 1791 (S) rather than Nodulisporium Preuss 1849 (A)}

The genus Hypoxylon, typified by $H$. fragiforme, is a well-known group of stromatic ascomycetes on rotting wood. Although a number of segregated genera are now recognized such as Annulohypoxylon, Biscogniauxia, and Nemania, many species still remain within Hypoxylon sensu stricto (Hsieh et al. 2005). Von Arx (1982), fide Deighton (1985), demonstrated the relationship of the asexual morph Nodulisporium ochraceum, type of Nodulisporium, to Hypoxylon fragiforme, thus these generic names are synonyms. Other species of Nodulisporium have been placed in various genera suggesting the artificial circumscription of this genus. Given the widespread use of Hypoxylon, the number of names, and priority, the use of Hypoxylon is recommended.

Use Microdochium Syd. \& P. Syd. 1924 (A) rather than Monographella Petr. later in 1924 (S)

The genus Microdochium, typified by $M$. phragmitis, was published a few months later than Monographella, typified by $M$. divergens, now regarded as a synonym of Microdochium nivale. Hernández-Restrepo et al. (2016) recognized the synonym of Microdochium and Monographella and considered Microdochium to be the best generic name to use for these fungi because Microdochium included more species and was more widely known than Monographella. They added six species to the 31 names in the genus Microdochium while Monographella includes only 15 names. In addition they epitypified the type of Microdochium, M. phragmitis, a species that had been shown to represent two sympatric species (Ernst et al. 2011). Thus, in agreement with Hernández-Restrepo et al. (2016), we recommend the protection of Microdochium over Monographella.

\section{Use Nemania Gray 1821 (S) rather than} Geniculosporium Chesters \& Greenh. 1964 (A) An asexual morph of Nemania serpens, type species of Nemania, was described as Geniculosporium serpens, type of Geniculosporium (Chesters \& Greenhalgh 1964), thus the generic names Nemania and Geniculosporium are synonyms. Nemania includes over 30 names while only four names have been placed in Geniculosporium. In addition, Nemania is well-known and has priority, thus we recommend the use of Nemania.

\section{Use Rosellinia De Not. 1844 (S) rather than Dematophora R. Hartig 1883 (A)}

The genus Rosellinia, typified by $R$. aquila, is a wellknown genus that has recently been monographed (Petrini 2013). A number of plant pathogenic species are included in Rosellinia such as $R$. bunodes causing black root rot of tropical woody plants and $R$. thelena causing root collar of hardwoods. Dematophora necatrix, type of Dematophora, is considered the asexual morph of $R$. necatrix, cause of white root rot (Petrini 2013), thus Rosellinia and Dematophora are synonyms. The only other species of Dematophora, $D$. glomerata, is considered the asexual morph of $R$. glomerata.
Given the widespread use of Rosellinia, the recent monographic account, its importance as a plant pathogen, and priority, we recommend the use of Rosellinia.

\section{Use Virgaria Nees 1816 (A) rather than} Ascovirgaria J.D. Rogers \& Y.-M. Ju 2002 (S)

The monotypic genus Ascovirgaria, typified by $A$. occulta, was described for the sexual morph of the type species of Virgaria, V. nigra, by Rogers \& Ju (2002), thus these generic names are synonyms. Nonaka et al. (2013) demonstrated that $A$. occulta was a synonym of $V$. nigra and that Virgaria was distinct from other genera in the Xylariaceae. Although some names have been transferred to other genera, Virgaria still includes 10 names and is more commonly used than Ascovirgaria. Given its priority and widespread use, Virgaria is recommended for use over Ascovirgaria.

Use Xylaria Hill ex Schrank 1789 (S) rather than Moelleroclavus Henn. 1902 (A), Xylocoremium J.D. Rogers 1984 (A), Arthroxylaria Seifert \& W. Gams 2002 (A) or Geniculisynnema Okane \& Nakagiri 2007 (A)

Xylaria is a well-known genus with many species such as Xylaria polymorpha, commonly known as dead man's fingers, also said to cause root rot of urban trees (Proffer 1988). The asexual morphs of species of Xylaria have been described in four genera. The monotype species of Moelleroclavus, M. penicillioides, has a sexual morph described as Xylaria moelleroclavus (Rogers et al. 1997) and Xylocoremium flabelliforme, monotype species of Xylocoremium, is the asexual morph of Xylaria cubensis (Rogers 1984), now known to be X. flabelliformis (Ju et al. 2016). Both Arthroxylaria and Geniculisynnema are monotypic genera proposed for asexual morphs not yet connected to a sexual morph but clearly within Xylaria based on rDNA sequences (Seifert et al. 2002, Okane \& Nakagiri 2007). The type species of Arthroxylaria, A. elegans, is herein placed in Xylaria. Although Stadler et al. (2013) connected Geniculisynnema with Nemania, a BLAST search with the ITS sequence of $G$. termiticola (AB274813), type species of Geniculisynnema, showed top matches with Xylaria species associated with termite nests.. These four generic names are now considered synonyms of Xylaria. Given its widespread use, the number of species, and priority, Xylaria is recommended for use.

New combinations:

Xylaria benjaminii Seifert \& W. Gams, nom. nov. MycoBank MB816839

Replaced name: Arthroxylaria elegans Seifert \& W. Gams, Czech Mycol. 53: 209 (2002).

Non Xylaria elegans Syd. \& P. Syd., Annls mycol. 5: 357 (1907).

Xylaria penicilliopsis (Henn.) Y.-M. Ju, comb. nov. MycoBank MB816837

Basionym: Moelleroclavus penicilliopsis Henn., Hedwigia 41: 15 (1902).

Synonym: Xylaria moelleroclavus J.D. Rogers et al., Mycol. Res. 101: 345 (1997). 
Xylaria termiticola (Okane \& Nakagiri) Y.-M. Ju, comb. nov.

MycoBank MB816838

Basionym: Geniculisynnema termiticola Okane \& Nakagiri, Mycoscience 48: 245 (2007).

\section{Sordariomycetidae incertae sedis}

\section{Use Brachysporium Sacc. 1886 (A) rather than Cryptadelphia Réblová \& Seifert 2004 (S)}

Brachysporium, typified by $B$. obovatum, is a widespread and well-established asexual genus that includes 113 species and varieties. The genus Cryptadelphia, typified by $C$. groenendalensis, was introduced for the sexual morphs of six species of Brachysporium (Réblová \& Seifert 2004b). The link between the sexual and asexual morphs was experimentally proven only for $B$. nigrum, which is the asexual morph of $C$. groenendalensis. The axenic cultures of $B$. obovatum and $B$. polyseptatum derived from ascospores yielded only sterile mycelium. Recently, C. fusiformis was described with its asexual morph regarded as B. fusiformis
(Markovskaja \& Treigiené 2007). Based on molecular sequence data, B. nigrum and B. polyseptatum form a strongly supported monophyletic clade (Réblová \& Seifert 2004b). If $B$. obovatum is congeneric with $B$. nigrum, then the generic names Brachysporium and Cryptadelphia should be treated as synonyms. Based on priority and the greater number of species, Brachysporium is recommended for use.

\section{Use Nigrospora Zimm. 1902 (A) rather than Khuskia H.J. Huds. 1963 (S)}

The monotype species of Khuskia, K. oryzae, was described as the sexual morph of Nigrospora oryzae, a well-known species of Nigrospora, by Hudson (1963). He also considered $N$. oryzae and N. panici, the type species of Nigrospora, to be congeneric, thus Nigrospora and Khuskia are synonyms. Nigrospora oryzae is reported from a variety of hosts including marine sponges (Ding et al. 2011) and as endophytes of plants (Peršoh et al. 2010) as well as causing plant diseases (Moshrefi-Zarandi et al. 2014). Given that Nigrospora has priority, includes fifteen names, and is more widely known than Khuskia, the use of Nigrospora is recommended.

Table 1. Names of pleomorphic genera in Sordariomycetes excluding Diaporthales, Hypocreales and Magnaporthales indicating those that are proposed for protection (including those which are asexually typified and recommended for use over sexually typified genera). For each genus the citation, type species and accepted name is given. NCF = Nomenclature Committee for Fungi.

\begin{tabular}{|c|c|c|}
\hline $\begin{array}{l}\text { Generic name recommended for use, } \\
\text { citation and type species }\end{array}$ & $\begin{array}{l}\text { Suppressed generic name(s), citation, type } \\
\text { species and currently accepted name }\end{array}$ & Action Required \\
\hline $\begin{array}{l}\text { Arthrinium Kunze, in Kunze \& Schmidt, } \\
\text { Mykol. Hefte 1: } 9.1817 . \\
\text { Typus: A. caricicola Kunze \& J.C. Schmidt } \\
\text { 1817. }\end{array}$ & $\begin{array}{l}\text { Apiospora Sacc. in Atti Soc. Veneto-Trent. Sci. Nat., } \\
\text { Padova, sér. } 4 \text { 4: } 85.1875 . \\
\text { Typus: A. montagnei Sacc. 1875, now regarded } \\
\text { as Arthrinium arundinis (Corda) Dyko \& B. Sutton } \\
1979 . \\
\text { Pteroconium Sacc. ex Grove in Hedwigia 55: } 146 . \\
1914 . \\
\text { Typus: P. asteroides Grove 1914, now regarded as } \\
\text { Arthrinium pterospermum (Cooke \& Massee) Arx } \\
\text { 1981. } \\
\text { Scyphospora L.A. Kantsch. in Bolêzni Rast. 17: } 87 \\
\text { (1928). } \\
\text { Typus: S. phyllostachydis L.A. Kantsch. 1928, now } \\
\text { regarded as Arthrinium hysterinum (Sacc.) P.M. } \\
\text { Kirk 1986. }\end{array}$ & $\begin{array}{l}\text { Asexual type. Protection needed by } \\
\text { NCF. }\end{array}$ \\
\hline $\begin{array}{l}\text { Brachysporium Sacc., Syll. Fung. 4: } 423 . \\
1886 . \\
\text { Typus: B. obovatum (Berk.) Sacc. 1886, } \\
\text { basionym: Helminthosporium obovatum } \\
\text { Berk. 1841. }\end{array}$ & $\begin{array}{l}\text { Cryptadelphia Réblová \& Seifert in Mycologia 96: } \\
\text { 348. } 2004 . \\
\text { Typus: C. groenendalensis (Sacc. et al.) Réblová \& } \\
\text { Seifert 2004, basionym: Zignoëlla groenendalensis } \\
\text { Sacc. et al. } 1884 \text {, now regarded as Brachysporium } \\
\text { nigrum (Link) S. Hughes } 1958 .\end{array}$ & $\begin{array}{l}\text { Asexual type. Protection needed by } \\
\text { NCF. }\end{array}$ \\
\hline $\begin{array}{l}\text { Calosphaeria Tul. \& C. Tul., Select. fung. } \\
\text { carpol. 2: 108. } 1863 . \\
\text { Typus: C. princeps Tul. \& C. Tul. } 1863 .\end{array}$ & $\begin{array}{l}\text { Calosphaeriophora Réblová et al. in Stud. Mycol. } \\
\text { 50: } 542.2004 . \\
\text { Typus: C. pulchella Réblová et al. 2004, now } \\
\text { regarded as Calosphaeria pulchella (Pers.) J. } \\
\text { Schröt. } 1897 \text {. }\end{array}$ & None. \\
\hline $\begin{array}{l}\text { Canalisporium Nawawi \& Kuthub. in } \\
\text { Mycotaxon 34: } 477.1989 . \\
\text { Typus: C. caribense (Hol.-Jech. \& Mercado) } \\
\text { Nawawi \& Kuthub. 1989, basionym: } \\
\text { Berkleasmium caribense Hol.-Jech. \& } \\
\text { Mercado 1984. }\end{array}$ & $\begin{array}{l}\text { Ascothailandia Sri-indr. et al. in Mycoscience 51: } \\
\text { 414. } 2010 . \\
\text { Typus: } \text { A. grenadoidea Sri-indr. et al. 2010, now } \\
\text { regarded as Canalisporium grenadoideum Sri-indr. } \\
\text { et al. } 2010 \text {. }\end{array}$ & $\begin{array}{l}\text { Asexual type. Protection needed by } \\
\text { NCF. }\end{array}$ \\
\hline
\end{tabular}


Table 1. (Continued).

\begin{tabular}{|c|c|c|}
\hline $\begin{array}{l}\text { Generic name recommended for use, } \\
\text { citation and type species }\end{array}$ & $\begin{array}{l}\text { Suppressed generic name(s), citation, type } \\
\text { species and currently accepted name }\end{array}$ & Action Required \\
\hline $\begin{array}{l}\text { Chaetomium Kunze, in Kunze \& Schmidt, } \\
\text { Mykol. Hefte 1: } 15.1817 . \\
\text { Typus: C. globosum Kunze } 1817 .\end{array}$ & $\begin{array}{l}\text { Botryotrichum Sacc. \& Marchal in Bull. Soc. Roy. } \\
\text { Bot. Belgique 24: 66. } 1885 . \\
\text { Typus: B. piluliferum Sacc. \& Marchal 1885, now } \\
\text { regarded as Chaetomium piluliferum J. Daniels } \\
\text { 1961. Although the synonym Sepedonium } \\
\text { albogriseum Balf.-Browne } 1952 \text { provides an } \\
\text { older name, C. piluliferum will be proposed for } \\
\text { conservation. } \\
\text { Trichocladium Harz in Bull. Soc. Imp. nat. Moscou } \\
\text { 44: } 125.1871 . \\
\text { Typus: T. asperum Harz } 1871 . \\
\text { Humicola Traaen in Nytt Mag. Natur. 52: } 31.1914 . \\
\text { Typus: H. fuscoatra Traaen } 1914 .\end{array}$ & None. \\
\hline $\begin{array}{l}\text { Chaetosphaerella E. Müll. \& C. Booth in } \\
\text { Trans. Brit. Mycol. Soc. 58: } 76.1972 . \\
\text { Typus: C. phaeostroma (Durieu \& Mont.) E. } \\
\text { Müll. \& C. Booth 1972, basionym: Sphaeria } \\
\text { phaeostroma Durieu \& Mont. } 1846\end{array}$ & $\begin{array}{l}\text { Oedemium Link, Sp. Pl., edn } 4 \text { 6(1): } 42.1824 . \\
\text { Typus: O. atrum Link 1824, now regarded as } \\
\text { Chaetosphaerella fusca (Fuckel) E. Müll. \& C. } \\
\text { Booth } 1972 . \\
\text { Veramycina Subram. in Kavaka 20/21: } 58.1995 . \\
\text { Typus: V. elegans Subram. 1995, now regarded as } \\
\text { Chaetosphaerella phaeostroma (Durieu \& Mont.) E. } \\
\text { Müll. \& C. Booth 1972. }\end{array}$ & $\begin{array}{l}\text { Protection needed by NCF for Chaeto- } \\
\text { sphaerella } 1972 \text { over Oedemium } 1824 .\end{array}$ \\
\hline $\begin{array}{l}\text { Chloridium Link in Mag. Gesell. Naturf. } \\
\text { Freunde, Berlin 3: } 13.1809 . \\
\text { Typus: C. viride Link 1805, now regarded } \\
\text { as Chloridium virescens (Pers.) W. Gams } \\
\text { \& Hol.-Jech. 1976, basionym Dematium } \\
\text { virescens Pers. 1794. }\end{array}$ & $\begin{array}{l}\text { Gonytrichum Nees \& T. Nees in Nova Acta Phys.- } \\
\text { Med. Acad. Caes. Leop.-Carol. Nat. Cur. 9: } 244 . \\
1818 . \\
\text { Typus: G. caesium Nees 1818, now regarded as } \\
\text { Chloridium caesium (Nees) Réblová \& Seifert } 2016 \\
\text { Melanopsammella Höhn. in Ann. Mycol. 17: } 121 . \\
1920 . \\
\text { Typus: M. inaequalis (Grove) Höhn. 1920, basionym: } \\
\text { Eriosphaeria inaequalis Grove, in Berlese \& Voglino } \\
\text { 1886, now regarded as Chloridium caesium (Nees) } \\
\text { Réblová \& Seifert } 2016 .\end{array}$ & $\begin{array}{l}\text { Asexual type. Protection needed by } \\
\text { NCF. }\end{array}$ \\
\hline $\begin{array}{l}\text { Colletotrichum Corda, Deutschl. Fl., 3(12): } \\
\text { 41. } 1837 . \\
\text { Typus: C. lineola Corda } 1832 .\end{array}$ & $\begin{array}{l}\text { Glomerella Spauld. \& H. Schrenk in Science 17: } \\
\text { 751. 1903. } \\
\text { Typus: G. cingulata (Stoneman) Spauld. \& H. } \\
\text { Schrenk 1903, now regarded as Colletotrichum } \\
\text { gloeosporioides (Penz.) Penz. \& Sacc. 1884. }\end{array}$ & $\begin{array}{l}\text { Asexual type. Protection needed by } \\
\text { NCF. }\end{array}$ \\
\hline $\begin{array}{l}\text { Collodiscula I. Hino \& Katum. in Bull. Fac. } \\
\text { Agric. Yamaguchi Univ. 6: 55. } 1955 . \\
\text { Typus: C. japonica I. Hino \& Katum. } 1955 .\end{array}$ & $\begin{array}{l}\text { Acanthodochium Samuels et al. in Mycotaxon 28: } \\
\text { 457. } 1987 . \\
\text { Typus: A. collodisculae Samuels et al. 1987, now } \\
\text { regarded as Collodiscula japonica I. Hino \& Katum. } \\
\text { 1955. }\end{array}$ & None. \\
\hline $\begin{array}{l}\text { Coniochaeta (Sacc.) Cooke in Grevillea } \\
\text { 16: 16. 1887, basionym: Rosellinia subgen. } \\
\text { Coniochaeta Sacc., Syll. Fung. 1: 269. } 1882 . \\
\text { Typus: C. ligniaria (Grev.) Cooke } 1887, \\
\text { basionym: Sphaeria ligniaria Grev. } 1824 .\end{array}$ & $\begin{array}{l}\text { Lecythophora Nannf. in Svensk Skogsvårdsförening } \\
\text { Tidskr. 3-4: 435. } 1934 . \\
\text { Typus: L. lignicola Nannf. 1934, now regarded as } \\
\text { Coniochaeta lignicola (Nannf.) Z.U. Khan et al. } \\
2013 .\end{array}$ & None. \\
\hline $\begin{array}{l}\text { Conioscypha Höhn. in Ann. Mycol. 2: } 58 . \\
\text { 1904. } \\
\text { Typus: C. lignicola Höhn. } 1904 .\end{array}$ & $\begin{array}{l}\text { Conioscyphascus Réblová \& Seifert in Stud. Mycol. } \\
\text { 50: } 100.2004 . \\
\text { Typus: C. varius Réblová \& Seifert 2004, now } \\
\text { regarded as Conioscypha varia Shearer 1973. }\end{array}$ & $\begin{array}{l}\text { Asexual type. Protection needed by } \\
\text { NCF. }\end{array}$ \\
\hline
\end{tabular}


Table 1. (Continued).

\begin{tabular}{|c|c|c|}
\hline $\begin{array}{l}\text { Generic name recommended for use, } \\
\text { citation and type species }\end{array}$ & $\begin{array}{l}\text { Suppressed generic name(s), citation, type } \\
\text { species and currently accepted name }\end{array}$ & Action Required \\
\hline $\begin{array}{l}\text { Cordana Preuss in Linnaea 24: 129. } 1851 . \\
\text { Typus: C. pauciseptata Preuss } 1851 .\end{array}$ & $\begin{array}{l}\text { Porosphaerella E. Müll. \& Samuels in Sydowia 35: } \\
\text { 151. } 1982 . \\
\text { Typus: P. cordanophora E. Müll. \& Samuels 1982, } \\
\text { now regarded as Cordana pauciseptata Preuss } \\
\text { 1851. } \\
\text { Pseudobotrytis Krzemien. \& Badura in Acta Soc. } \\
\text { Bot. Pol. 23: } 761.1954 . \\
\text { Typus: P. fusca Krzemien. \& Badura 1954, now } \\
\text { regarded as Cordana terrestris (Timonin) Hern.- } \\
\text { Rest. et al. } 2014 \text {. }\end{array}$ & $\begin{array}{l}\text { Asexual type. Protection needed by } \\
\text { NCF. }\end{array}$ \\
\hline $\begin{array}{l}\text { Corollospora Werderm. in Notizbl. Bot. } \\
\text { Gart. Berlin-Dahlem 8: } 248.1922 . \\
\text { Typus: Corollospora maritima Werderm. } \\
\text { 1922. }\end{array}$ & $\begin{array}{l}\text { Varicosporina Meyers \& Kohlm. in Canad. J. Bot. } \\
\text { 43: 916. } 1965 . \\
\text { Typus: V. ramulosa Meyers \& Kohlm. 1965, now } \\
\text { regarded as Corollospora ramulosa (Meyers \& } \\
\text { Kohlm.) Abdel-Wahab } 2016 . \\
\text { Halosigmoidea Nakagiri et al. in Bot. Mar. 52: } 355 \text {. } \\
\text { 2009. } \\
\text { Typus: H. luteola (Nakagiri \& Tubaki) Nakagiri et } \\
\text { al. 2009, basionym: Sigmoidea luteola Nakagiri \& } \\
\text { Tubaki 1982, now regarded as Corollospora luteola } \\
\text { Nakagiri \& Tubaki 1982. }\end{array}$ & None. \\
\hline $\begin{array}{l}\text { Cylindrotrichum Bonord., Handb. Allgem. } \\
\text { mykol.: } \mathbf{8 8}(1851) \text {. } \\
\text { Typus: C. oligospermum (Corda) Bonord. } \\
\text { 1851, basionym: Menispora oligosperma } \\
\text { Corda } 1838 .\end{array}$ & $\begin{array}{l}\text { Reticulascus Réblová \& W. Gams in Stud. Mycol. } \\
\text { 68: 180. } 2011 . \\
\text { Typus: R. tulasneorum (Réblová \& W. } \\
\text { Gams) Réblová \& W. Gams 2010, basionym: } \\
\text { Chaetosphaeria tulasneorum Réblová \& W. } \\
\text { Gams 1999, now regarded as Cylindrotrichum } \\
\text { oligospermum (Corda) Bonord. 1851. }\end{array}$ & $\begin{array}{l}\text { Asexual type. Protection needed by } \\
\text { NCF. }\end{array}$ \\
\hline $\begin{array}{l}\text { Daldinia Ces. \& De Not. in Comment. Soc. } \\
\text { Crittog. Ital. 1(4): 197. } 1863 . \\
\text { Typus: D. concentrica (Bolton) Ces. \& De } \\
\text { Not. 1863, basionym: Sphaeria concentrica } \\
\text { Bolton } 1792 \text {. }\end{array}$ & $\begin{array}{l}\text { Annellosporium M.L. Davey in Karstenia 50: } 3 . \\
2010 . \\
\text { Typus: A. nemorosum M.L. Davey 2010, now } \\
\text { Daldinia nemorosa (M.L. Davey) M. Stadler et al. } \\
2014 . \\
\text { Versiomyces Whalley \& Watling in Notes R. bot. } \\
\text { Gdn Edinb. 45: } 401.1989 \text {. } \\
\text { Typus: V. cahuchucosus Whalley \& Watling 1989, } \\
\text { now regarded as Daldinia cahuchucosus (Whalley } \\
\text { \& Watling) M. Stadler \& Læssøe } 2014 \text {. }\end{array}$ & None. \\
\hline $\begin{array}{l}\text { Diachora Jul. Müll. in Jahrb. Wiss. Bot. 25: } \\
\text { 623. } 1893 . \\
\text { Typus: D. onobrychidis (DC.) Jul. Müll. 1893, } \\
\text { basionym: Xyloma onobrychidis DC. } 1815 .\end{array}$ & $\begin{array}{l}\text { Diachorella Höhn. in Hedwigia 60: 192. } 1918 . \\
\text { Typus: D. onobrychidis (DC.) Höhn. 1918, basionym: } \\
\text { Xyloma onobrychidis DC. 1815, now regarded as } \\
\text { Diachora onobrychidis (DC) Jul. Müll. } 1893 .\end{array}$ & None. \\
\hline $\begin{array}{l}\text { Diatrype Fr., Summa veg. Scand. 2: } 384 . \\
1849 . \\
\text { Typus: D. disciformis (Hoffm.) Fr. } 1849 \text {, } \\
\text { basionym: Sphaeria disciformis Hoffm. } 1787 .\end{array}$ & $\begin{array}{l}\text { Libertella Desm. in Ann. Sci. Nat. (Paris) sér. } 119 \text { : } \\
\text { 275. } 1830 . \\
\text { Typus: L. betulina Desm. 1830, now regarded as } \\
\text { Diatrype stigma (Hoffm.) Fr. 1849. }\end{array}$ & $\begin{array}{l}\text { Protection needed by NCF for Diatrype } \\
1849 \text { over Libertella } 1830 .\end{array}$ \\
\hline $\begin{array}{l}\text { Dyrithiopsis L. Cai et al. in Mycologia 95: } \\
\text { 912. } 2003 . \\
\text { Typus: D. lakefuxianensis L. Cai et al. } 2003 .\end{array}$ & $\begin{array}{l}\text { Monochaetiopsis L. Cai et al. in Mycologia 95: } 913 . \\
2003 . \\
\text { Typus: M. lakefuxianensis L. Cai et al. 2003, now } \\
\text { regarded as Dyrithiopsis lakefuxianensis L. Cai et } \\
\text { al. } 2003 \text {. }\end{array}$ & None. \\
\hline
\end{tabular}


Table 1. (Continued).

\begin{tabular}{|c|c|c|}
\hline $\begin{array}{l}\text { Generic name recommended for use, } \\
\text { citation and type species }\end{array}$ & $\begin{array}{l}\text { Suppressed generic name(s), citation, type } \\
\text { species and currently accepted name }\end{array}$ & Action Required \\
\hline $\begin{array}{l}\text { Hyalotiopsis Punith. in Mycol. Pap. 119: } 12 . \\
1970 . \\
\text { Typus: H. subramanianii (Agnihothr. \& } \\
\text { Luke) Punith. 1970, basionym: Hyalotiella } \\
\text { subramanianii Agnihothr. \& Luke 1970. }\end{array}$ & $\begin{array}{l}\text { Ellurema Nag Raj \& W.B. Kendr. in Sydowia 38: } \\
\text { 178. } 1986 . \\
\text { Typus: E. indica (Punith.) Nag Raj \& W.B. Kendr. } \\
\text { 1986, basionym: Massaria indica Punith. 1970, now } \\
\text { regarded as Hyalotiopsis subramanianii (Agnihothr. } \\
\text { \& Luke) Punith. 1970. }\end{array}$ & $\begin{array}{l}\text { Asexual type. Protection needed by } \\
\text { NCF. }\end{array}$ \\
\hline $\begin{array}{l}\text { Hypocreodendron Henn. in Hedwigia 36: } \\
\text { 223. } 1897 . \\
\text { Typus: H. sanguineum Henn. } 1897 .\end{array}$ & $\begin{array}{l}\text { Discoxylaria J.C. Lindq. \& J.E. Wright in Darwiniana } \\
\text { 13: } 139.1964 . \\
\text { Typus: Discoxylaria myrmecophila J.C. Lindq. \& J.E. } \\
\text { Wright } 1964 \text {, now regarded as Hypocreodendron } \\
\text { sanguineum Henn. } 1897 .\end{array}$ & $\begin{array}{l}\text { Asexual type. Protection needed by } \\
\text { NCF. }\end{array}$ \\
\hline $\begin{array}{l}\text { Hypoxylon Bull., Hist. Champ. Fr. 1: } 168 . \\
1791 . \\
\text { Typus: H. coccineum Bull. 1791, now } \\
\text { regarded as Hypoxylon fragiforme (Pers.) J. } \\
\text { Kickx f. 1835, basionym Sphaeria fragiformis } \\
\text { Pers. } 1794 .\end{array}$ & $\begin{array}{l}\text { Nodulisporium Preuss in Klotzschii Herb. Viv. } \\
\text { Mycol.: no. } 1272.1849 . \\
\text { Typus: N. ochraceum Preuss 1849, now regarded } \\
\text { as Hypoxylon fragiforme (Pers.) J. Kickx f. } 1835 .\end{array}$ & None. \\
\hline $\begin{array}{l}\text { Juncigena Kohlm. et al. in Bot. Mar. 40: } 291 . \\
1997 . \\
\text { Typus: J. adarca Kohlm. et al. } 1997 .\end{array}$ & $\begin{array}{l}\text { Moheitospora Abdel-Wahab et al. in Mycol. Progr. } \\
\text { 9: } 551.2010 . \\
\text { Typus: M. fruticosae Abdel-Wahab et al. 2010, now } \\
\text { regarded as Juncigena fruticosae (Abdel-Wahab et } \\
\text { al.) A.N. Mill. \& Shearer } 2016 \text {. }\end{array}$ & None. \\
\hline $\begin{array}{l}\text { Knoxdaviesia M.J. Wingf. et al. in Mycologia } \\
\text { 80: } 26.1988 . \\
\text { Typus: K. proteae M.J. Wingf. et al. } 1988 .\end{array}$ & $\begin{array}{l}\text { Gondwanamyces G.J. Marais \& M.J. Wingf. in } \\
\text { Mycologia 90: 139. } 1998 . \\
\text { Typus: G. proteae (M.J. Wingf. et al.) G.J. Marais } \\
\text { \& M.J. Wingf. 1998, basionym: Ceratocystiopsis } \\
\text { proteae M.J. Wingf. et al. 1988, now regarded as } \\
\text { Knoxdaviesia proteae M.J. Wingf. et al. 1988. }\end{array}$ & $\begin{array}{l}\text { Asexual type. Protection needed by } \\
\text { NCF. }\end{array}$ \\
\hline $\begin{array}{l}\text { Lasiosphaeris Clem., Gen. Fungi: } 173 . \\
1909 . \\
\text { Typus: L. hispida (Tode) Clem. } 1909 .\end{array}$ & $\begin{array}{l}\text { Lasiadelphia Réblová \& W. Gams in Fungal Divers. } \\
\text { 46: 82. } 2011 . \\
\text { Typus: L. lasiosphaeriae (W. Gams) Réblová \& } \\
\text { W. Gams 2011, now regarded as Lasiosphaeris } \\
\text { hispida (Tode) Clem. } 1909 .\end{array}$ & None. \\
\hline $\begin{array}{l}\text { Mammaria Ces. ex Rabenh. in Bot. Zeit. 12: } \\
\text { 190. } 1854 . \\
\text { Typus: M. echinobotryoides Ces. } 1854 .\end{array}$ & $\begin{array}{l}\text { Pseudocercophora Subram. \& Sekar in J. } \\
\text { Singapore Natl. Acad. Sci. 15: } 58.1986 . \\
\text { Typus: P. ingoldii Subram. \& Sekar 1986, now } \\
\text { regarded as Mammaria echinobotryoides Ces. } \\
1854 .\end{array}$ & $\begin{array}{l}\text { Asexual type. Protection needed by } \\
\text { NCF. }\end{array}$ \\
\hline $\begin{array}{l}\text { Melanospora Corda, Icon. Fung. 1: } 24 . \\
1837 . \\
\text { Typus: M. zamiae Corda } 1837 .\end{array}$ & $\begin{array}{l}\text { Gonatobotrys Corda, Pracht-Fl. Eur. Schimmelbild.: } \\
\text { 9. } 1839 . \\
\text { Typus: G. simplex Corda 1839, now regarded as } \\
\text { Melanospora simplex (Corda) D. Hawks. } 2016 .\end{array}$ & None. \\
\hline $\begin{array}{l}\text { Menispora Pers., Mycol. Eur. 1: } 32.1822 . \\
\text { Typus: M. glauca (Link) Pers. 1822, } \\
\text { basionym: Camptosporium glaucum Link in } \\
\text { Ehrenberg } 1827 .\end{array}$ & $\begin{array}{l}\text { Zignoëlla Sacc. in Michelia 1: } 346.1878 . \\
\text { Typus: Z. pulviscula (Curr.) Sacc. 1878, now } \\
\text { regarded as Menispora caesia Preuss 1851. }\end{array}$ & $\begin{array}{l}\text { Asexual type. Protection needed by } \\
\text { NCF. }\end{array}$ \\
\hline $\begin{array}{l}\text { Menisporopsis S. Hughes in Mycol. Pap. } \\
\text { 48: 59. } 1952 . \\
\text { Typus: M. theobromae S. Hughes } 1952 .\end{array}$ & $\begin{array}{l}\text { Menisporopascus Matsush. in Matsush. Mycol. } \\
\text { Mem. 10: } 141.2003 . \\
\text { Typus: M. kobensis Matsush. 2003, now regarded } \\
\text { as Menisporopsis kobensis Matsush. } 2003 \text {. }\end{array}$ & $\begin{array}{l}\text { Asexual type. Protection needed by } \\
\text { NCF. }\end{array}$ \\
\hline $\begin{array}{l}\text { Microdochium Syd. \& P. Syd. in Ann. Mycol. } \\
\text { 22(3/6): 267. Published on } 15 \text { Nov } 1924 . \\
\text { Typus: M. phragmitis Syd. \& P. Syd. } 1924 .\end{array}$ & $\begin{array}{l}\text { Monographella Petr. in Ann. Mycol. } 22 \text { (1/2): } 144 . \\
\text { Published } 20 \text { Jun } 1924 . \\
\text { Typus: M. divergens (Rehm) Petr. 1924, basionym: } \\
\text { Sphaerulina divergens Rehm 1913, now regarded } \\
\text { as Microdochium nivale (Fr.) Samuels \& I.C. Hallett } \\
\text { 1983. }\end{array}$ & $\begin{array}{l}\text { Protection needed by NCF for } \\
\text { Microdochium (Jun 1924) over } \\
\text { Monographella (Nov 1924). }\end{array}$ \\
\hline
\end{tabular}

Typus. H. subramaniar Luke) Punith. 1970, basionym: Hyalotiella Hypocreodendron Henn. in Hedwigia 36 223. 1897

Typus: $H$. sanguineum Henn. 1897.

Hypoxylon Bull., Hist. Champ. Fr. 1: 168.

Pers. 1794. 1997

9: 551.2010 regarded as Juncigena fruticosae (Abdel-Wahab et Gondwanamyces G.J. Marais \& M.J. Wingf. in ycologia 90: 139. 1998

46: 82. 2011. Gams 2011 , non Pseudocercophora Subram \& Sekar in J. Singapore Natl. Acad Sci. 15: 58, 1986.

Typus: G. simplex Corda 1839, now regarded as Melanospora simplex (Corda) D. Hawks. 2016.

Asexual type. Protection needed by Typus: Z. pulviscula (Curr.) Sacc. 1878, now Menisporopascus Matsush in Matsush Mycol. Mem. 10: 141. 2003.

Typus: M. kobensis Matsush. 2003, now regarded Published 20 Jun 1924 1983. 
Table 1. (Continued).

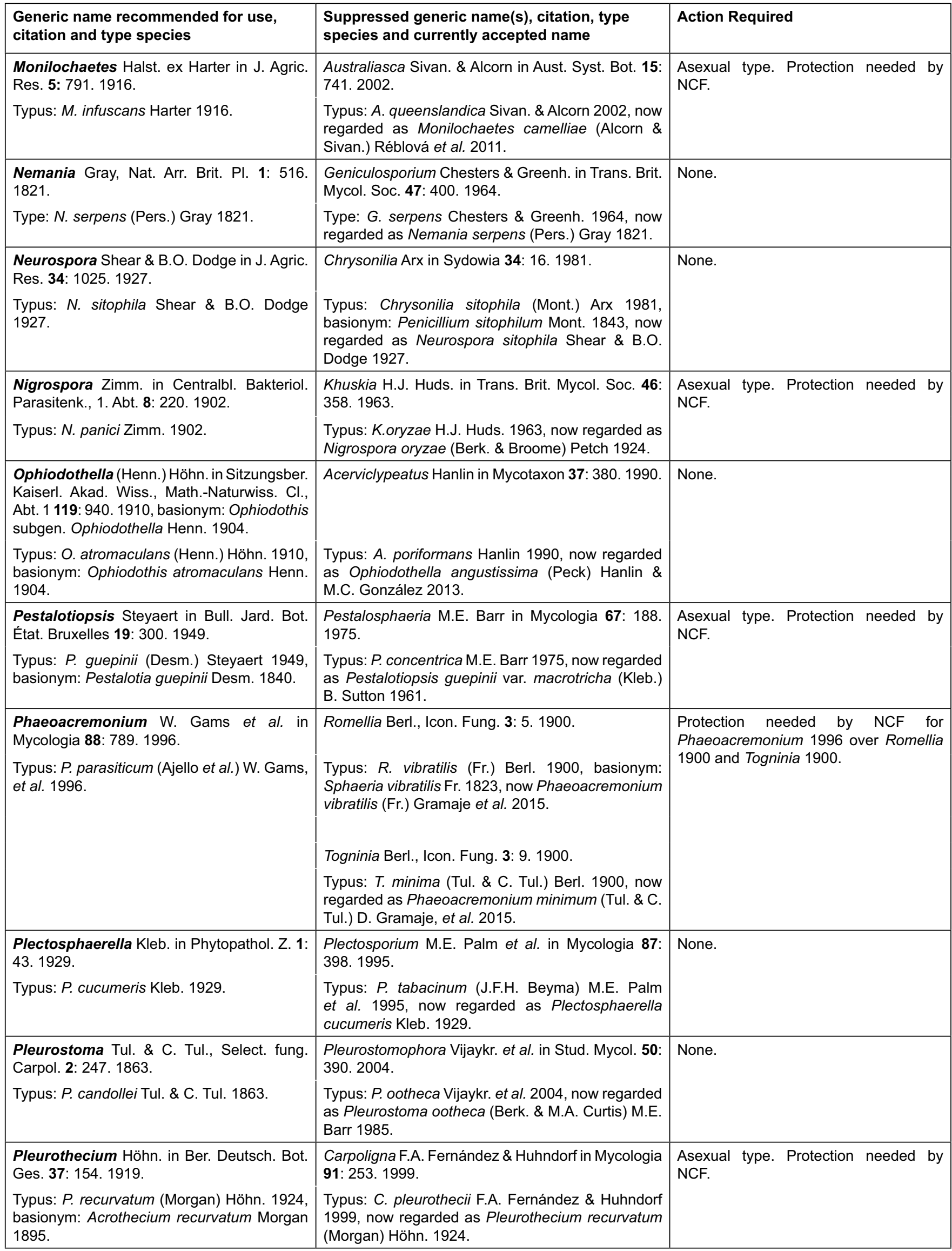


Table 1. (Continued).

\begin{tabular}{|c|c|c|}
\hline $\begin{array}{l}\text { Generic name recommended for use, } \\
\text { citation and type species }\end{array}$ & $\begin{array}{l}\text { Suppressed generic name(s), citation, type } \\
\text { species and currently accepted name }\end{array}$ & Action Required \\
\hline $\begin{array}{l}\text { Polystigma DC., in de Candolle \& Lamarck, } \\
\text { FI. Franç., edn } 3 \text { 6: } 164.1815 . \\
\begin{array}{l}\text { Typus: P. rubrum (Pers.) DC. 1815, } \\
\text { basionym: Xyloma rubrum Pers. } 1800 .\end{array}\end{array}$ & $\begin{array}{l}\text { Polystigmina Sacc., Syll. Fung. 3: 622. } 1884 . \\
\text { Typus: P. rubra (Pers.) Sacc. 1884, basionym: } \\
\text { Xyloma rubrum Pers. 1800, now regarded as } \\
\text { Polystigma rubrum (Pers.) DC. } 1815 . \\
\text { Rhodoseptoria Naumov in Bull. Soc. Mycol. Fr. 29: } \\
\text { 278. } 1913 \text {. } \\
\text { Typus: } R \text {. ussuriensis Naumov 1913, now regarded } \\
\text { as Polystigma rubrum (Pers.) DC. } 1815 . .\end{array}$ & None. \\
\hline $\begin{array}{l}\text { Pseudothiella Petr. in Hedwigia 68: } 257 . \\
1928 . \\
\text { Typus: P. hirtellae (Henn.) Petr. 1928. }\end{array}$ & $\begin{array}{l}\text { Pseudothiopsella Petr. in Hedwigia 68: 259. } 1928 . \\
\text { Typus: P. hirtellae Petr. 1928, now regarded as } \\
\text { Pseudothiella hirtellae (Henn.) Petr. } 1928 .\end{array}$ & None. \\
\hline $\begin{array}{l}\text { Rosellinia De Not. in Giorn. Bot. ital. 1: } 334 . \\
1844 . \\
\text { Typus: R. aquila (Fr.) Ces. \& De Not. } 1844 .\end{array}$ & $\begin{array}{l}\text { Dematophora R. Hartig in Untersuch. Forstbot. Inst. } \\
\text { München 3: } 95.1883 . \\
\text { Typus: D. necatrix R. Hartig 1883, now regarded as } \\
\text { Rosellinia necatrix Berl. ex Prill. } 1904\end{array}$ & None. \\
\hline $\begin{array}{l}\text { Seimatosporium Corda, in Sturm, Deutschl. } \\
\text { FI., } 3 \text { Abt. 3(13): } 79.1833 . \\
\text { Typus: S. rosae Corda } 1833 .\end{array}$ & $\begin{array}{l}\text { Discostroma Clem., Gen. Fung.: 50. } 1909 . \\
\text { Typus: Discostroma rehmii (Schnabl) Clem. } \\
\text { 1909, basionym: Curreya rehmii Schnabl 1892, } \\
\text { a synonym of D. massarina (Sacc.) Arx 1974, } \\
\text { basionym: Metasphaeria massarina Sacc. 1884, } \\
\text { now regarded as Seimatosporium massarina } \\
\text { (Sacc.) Jaklitsch \& Voglmayr 2016. }\end{array}$ & $\begin{array}{l}\text { Asexual type. Protection needed by } \\
\text { NCF. }\end{array}$ \\
\hline $\begin{array}{l}\text { Seiridium Nees, Syst. Pilze: 22. } 1816 . \\
\text { Typus: S. marginatum Nees } 1816 .\end{array}$ & $\begin{array}{l}\text { Blogiascospora Shoemaker et al. in Canad. J. Bot. } \\
\text { 44: 248. } 1966 . \\
\text { Typus: B. marginata (Fuckel) Shoemaker et al. } \\
\text { 1966, basionym: Massaria marginata Fuckel } 1873 \text {, } \\
\text { now regarded as Seiridium marginatum Nees } 1816 .\end{array}$ & $\begin{array}{l}\text { Asexual type. Protection needed by } \\
\text { NCF. }\end{array}$ \\
\hline $\begin{array}{l}\text { Sphaeronaemella P. Karst. in Hedwigia 23: } \\
\text { 17. } 1884 . \\
\text { Typus: S. helvellae (P. Karst.) P. Karst. 1884, } \\
\text { basionym: Sphaeria helvellae P. Karst. } 1867 .\end{array}$ & $\begin{array}{l}\text { Gabarnaudia Samson \& W. Gams in Stud. Mycol. } \\
\text { 6: 88. } 1974 \text {. } \\
\text { Typus: G. betae (Delacr.) Samson \& W. Gams, in } \\
\text { Samson 1974, basionym: Oospora betae Delacr. } \\
\text { 1897, now regarded as Sphaeronaemella betae } \\
\text { (Delacr.) Z.W. De Beer \& M.J. Wingf. } 2013 \text {. }\end{array}$ & None. \\
\hline $\begin{array}{l}\text { Sporoschisma Berk. \& Broome, in Berkeley, } \\
\text { Gard. Chron. 1847: 540. } 1847 . \\
\text { Typus: S. mirabile Berk. \& Broome } 1847 .\end{array}$ & $\begin{array}{l}\text { Melanochaeta E. Müll. et al. in Revue Mycol. 33: } \\
\text { 377. } 1969 . \\
\text { Typus: M. hemipsila (Berk. \& Broome) E. Müll., } \\
\text { et al. 1969, basionym: Sphaeria hemipsila Berk. } \\
\text { \& Broome 1873, now regarded as Sporoschisma } \\
\text { hemipsila (Berk. \& Broome) Zelski et al. 2014. }\end{array}$ & $\begin{array}{l}\text { Asexual type. Protection needed by } \\
\text { NCF. }\end{array}$ \\
\hline $\begin{array}{l}\text { Sporoschismopsis Hol.-Jech. \& Hennebert } \\
\text { in Bull. Jard. Bot. Nat. Belgique. Bruxelles } \\
\text { 42: 385. } 1972 . \\
\text { Typus: S. moravica Hol.-Jech. \& Hennebert } \\
\text { 1972. }\end{array}$ & $\begin{array}{l}\text { Porosphaerellopsis Samuels \& E. Müll. in Sydowia } \\
\text { 35: 143. } 1982 \text {. } \\
\text { Typus: P. sporoschismophora (Samuels \& E. Müll.) } \\
\text { E. Müll. \& Samuels 1982, basionym: Porosphaeria } \\
\text { sporoschismophora Samuels \& E. Müll. 1978, now } \\
\text { regarded as Sporoschismopsis sporoschismophora } \\
\text { (Samuels \& E. Müll.) Réblová 2014. }\end{array}$ & $\begin{array}{l}\text { Asexual type. Protection needed by } \\
\text { NCF. }\end{array}$ \\
\hline $\begin{array}{l}\text { Stanjehughesia Subram. in Proc. Indian } \\
\text { Acad. Sci., B, Biol. Sci. 58(4): 184. } 1992 . \\
\text { Type: S. hormiscioides (Corda) Subram. } \\
\text { 1992, basionym: Sporidesmium } \\
\text { hormiscioides Corda } 1838 .\end{array}$ & $\begin{array}{l}\text { Umbrinosphaeria Réblová in Mycotaxon 71: } 17 . \\
1999 . \\
\text { Type: U. caesariata (Clinton \& Peck) Réblová 1999, } \\
\text { basionym: Sphaeria caesariata Clinton \& Peck, } \\
\text { in Peck 1878, now regarded as Stanjehughesia } \\
\text { hormiscioides (Corda) Subram. 1992. }\end{array}$ & $\begin{array}{l}\text { Asexual type. Protection needed by } \\
\text { NCF. }\end{array}$ \\
\hline
\end{tabular}


Table 1. (Continued).

\begin{tabular}{|c|c|c|}
\hline $\begin{array}{l}\text { Generic name recommended for use, } \\
\text { citation and type species }\end{array}$ & $\begin{array}{l}\text { Suppressed generic name(s), citation, type } \\
\text { species and currently accepted name }\end{array}$ & Action Required \\
\hline $\begin{array}{l}\text { Stromatographium Höhn. in Denkschr. } \\
\text { Kaiserl. Akad. Wiss., Math.-Naturwiss. KI. } \\
\text { 83: 37. 1907. } \\
\text { Typus: S. stromaticum (Berk.) Höhn. 1907, } \\
\text { basionym: Stilbum stromaticum Berk. 1843. }\end{array}$ & $\begin{array}{l}\text { Fluviostroma Samuels \& E. Müll. in Sydowia 33: } \\
\text { 283. } 1980 . \\
\text { Typus: F. wrightii Samuels \& E. Müll. 1980, now } \\
\text { regarded as Stromatographium stromaticum } \\
\text { (Berk.) Höhn. } 1907 .\end{array}$ & None. \\
\hline $\begin{array}{l}\text { Togniniella Réblová et al. in Stud. Mycol. } \\
\text { 50: 543. } 2004 \text {. } \\
\text { Typus: T. acerosa Réblová et al. } 2004 \text {. }\end{array}$ & $\begin{array}{l}\text { Phaeocrella Réblová et al. in Stud. Mycol. 50: } 545 . \\
2004 . \\
\text { Typus: P. acerosa Réblová et al. 2004, now } \\
\text { regarded as Togniniella acerosa Réblová et al. } \\
2004 .\end{array}$ & None. \\
\hline $\begin{array}{l}\text { Torpedospora Meyers in Mycologia 49: } 496 . \\
1957 . \\
\text { Typus: T. radiata Meyers } 1957 .\end{array}$ & $\begin{array}{l}\text { Glomerulispora Abdel-Wahab \& Nagah. in Mycol. } \\
\text { Progr. 9: 552. } 2010 . \\
\text { Typus: G. mangrovei Abdel-Wahab \& Nagah. 2010, } \\
\text { now regarded as Torpedospora mangrovei (Abdel- } \\
\text { Wahab \& Nagah.) E.B.G. Jones \& Abdel-Wahab } \\
\text { 2016. }\end{array}$ & None. \\
\hline $\begin{array}{l}\text { Virgaria Nees, Syst. Pilze: } \mathbf{5 4 . 1 8 1 6 .} \\
\text { Typus: V. nigra (Link) Nees 1817, basionym: } \\
\text { Botrytis nigra Link } 1809 .\end{array}$ & $\begin{array}{l}\text { Ascovirgaria J.D. Rogers \& Y.M. Ju in Canad. J. } \\
\text { Bot. 80: } 478.2002 . \\
\text { Typus: A. occulta J.D. Rogers \& Y.M. Ju 2002, now } \\
\text { regarded as Virgaria nigra (Link) Nees } 1817 .\end{array}$ & $\begin{array}{l}\text { Asexual type. Protection needed by } \\
\text { NCF. }\end{array}$ \\
\hline $\begin{array}{l}\text { Xylaria Hill ex Schrank, Baier. FI. 1: } 200 . \\
\begin{array}{l}1789 . \\
\text { Typus: X. hypoxylon (L.) Grev. 1824, } \\
\text { basionym: Clavaria hypoxylon L. } 1753 .\end{array}\end{array}$ & $\begin{array}{l}\text { Moelleroclavus Henn. in Hedwigia 41: 15. } 1902 . \\
\text { Typus: M. penicilliopsis Henn. 1902, now regarded } \\
\text { as Xylaria penicilliopsis (Henn.) Y.M. Ju } 2016 . \\
\text { Xylocoremium J.D. Rogers in Mycologia 76: } 913 . \\
1984 . \\
\text { Typus: X. flabelliforme (Schwein.) J.D. Rogers } \\
\text { 1984, basionym: Sphaeria flabelliformis Schwein., } \\
\text { in Fries } 1828, \text { now regarded as Xylaria flabelliformis } \\
\text { (Schwein.) Berk. \& M.A. Curtis } 1868 . \\
\text { Geniculisynnema Okane \& Nakagiri in Mycoscience } \\
\text { 48: } 245.2007 . \\
\text { Typus: G. termiticola Okane \& Nakagiri 2007, now } \\
\text { regared as Xylaria termiticola (Okane \& Nakagiri) } \\
\text { Y.-M. Ju 2016. } \\
\text { Arthroxylaria Seifert \& W. Gams in Czech Mycol. } \\
\text { 53: } 299.2002 . \\
\text { Typus: A. elegans Seifert \& W. Gams 2002, now } \\
\text { regarded as Xylaria benjaminii Seifert \& W. Gams } \\
\text { 2016. }\end{array}$ & None. \\
\hline
\end{tabular}

\section{REFERENCES}

Abdel-Wahab MA, Nagahama T, Abdel-Aziz FA (2009) Two new Corollospora species and one new anamorph based on morphological and molecular data. Mycoscience 50: 147-155.

Abdel-Wahab MA, Pang KL, Nagahama T, Abdel-Aziz FA, Jones EBG (2010) Phylogenetic evaluation of anamorphic species of Cirrenalia and Cumulospora with the description of eight new genera and four new species. Mycological Progress 9: 537-558. Arx JA von (1957) Die Arten der Gattung Colletotrichum Cda. Phytopathologische Zeitschrift 29: 413-468.
Arx JA von (1981) On Monilia sitophila and some families of Ascomycetes. Sydowia 34: 13-29.

Arx JA von (1982) The genus Dicyma, its synonyms and related fungi. Proceedings, Koninklijke Nederlandse Akademie van Wetenschappen C 85: 21-28.

Arzanlou M, Groenewald JZ, Gams W, Braun U, Shin HD et al. (2007) Phylogenetic and morphotaxonomic revision of Ramichloridium and allied genera. Studies of Mycology 58: 57-93.

Barr ME (1975) Pestalosphaeria, a new genus in the Amphisphaeriaceae. Mycologia 67: 187-194.

Berbegal M, Garcia-Jimenez J, Armengol J (2014) First report of 
Calosphaeria pulchella causing canker and branch dieback of sweet cherry trees in Spain. Plant Disease 98: 1008.

Booth C (1957) Studies of pyrenomycetes: I. Four species of Chaetosphaeria, two with Catenularia conidia. II. Melanopsamma pomiformis and its Stachybotrys conidia. Mycological Papers 68: $1-27$.

Booth C (1958) The genera Chaetosphaeria and Thaxteria in Britain. Naturalist 1958: 83-90.

Braun U (2013) (2210 - 2232) Proposals to conserve the teleomorphtypified name Blumeria against the anamorph-typified name Oidium and twenty-two teleomorph-typified powdery mildew species names against competing anamorph-typified names (Ascomycota : Erysiphaceae).Taxon 62: 1328-1331.

Brockmann I (1976) Untersuchungen ueber die Gattung Discostroma Clements (Ascomycetes). Sydowia 28: 275-338.

Cannon PF (1991) A revision of Phyllachora and some similar genera on the host family Leguminosae. Mycological Papers 163: 1-302.

Cannon PF (1996) Systematics and diversity of the Phyllachoraceae associated with Rosaceae, with a monograph of Polystigma. Mycological Research 100: 1409-1427.

Cannon PF, Damm U, Johnston PR, Weir BS (2012) Colletotrichumcurrent status and future directions. Studies in Mycology 73: 181-213.

Cannon PF, Hawksworth DL (1982) A re-evaluation of Melanospora Corda and similar Pyrenomycetes, with a revision of the British species. Botanical Journal of the Linnean Society 84: 115-160.

Carlucci A, Raimondo ML, Santos J, Phillips AJL (2012) Plectosphaerella species associated with root and collar rots of horticultural crops in southern Italy. Persoonia 28: 34-48.

Chesters CGC, Greenhalgh GN (1964) Geniculosporium serpens gen. et sp. nov., the imperfect state of Hypoxylon serpens. Transactions of the British Mycological Society 47: 393-401.

Clements FE (1909) The Genera of Fungi. Minneapolis: H.W. Wilson.

Clements FE, Shear C (1931) The Genera of Fungi. New York: H. W. Wilson.

Constantinescu O, Holm K, Holm L (1995) Teleomorph-anamorph connections in ascomycetes: the anamorphs of three species of Chaetosphaeria. Mycological Research 99: 585-592.

Crous PW, Gams W, Wingfield MJ, van Wyk PS (1996) Phaeoacremonium gen. nov. associated with wilt and decline diseases of woody hosts and human infections. Mycologia $\mathbf{8 8}$ : 786-796.

Crous PW, Groenewald JZ (2013) A phylogenetic re-evaluation of Arthrinium. IMA Fungus 4: 133-154.

Crous PW, Verkley GJM, Christensen M, Castaneda-Ruiz RF, Groenewald JZ (2012) How important are conidial appendages? Persoonia 28: 126-137.

Damm U, Cannon PF, Woudenberg JHC, Crous PW (2012) The Colletotrichum acutatum species complex. Studies in Mycology 73: 37-113.

Damm U, Fourie PH, Crous PW (2010) Coniochaeta (Lecythophora), Collophora gen. nov. and Phaeomoniella species associated with wood necroses of Prunus trees. Persoonia 24: 60-80.

Damm U, Woudenberg JHC, Cannon PF, Crous PW (2009) Colletotrichum species with curved conidia from herbaceous hosts. Fungal Diversity 39: 45-87.

DanielH-M, Lachance M-A, CPKurtzman (2014)On the reclassification of species assigned to Candida and other ascomycetous yeast genera based on phylogenetic circumscription. Antonie van Leeuwenhoek 10: 67-84.
Daniels J (1961) Chaetomium piluliferum sp. nov., the perfect state of Botryotrichum piluliferum. Transactions of the British Mycological Society 44: 79-86.

de Beer ZW, Seifert KA, Wingfield MJ (2013) A nomenclator for ophiostomatoid genera and species in the Ophiostomatales and Microascales. CBS Biodiversity Series 12: 245-322.

Deighton FC (1985) Some species of Nodulisporium. Transactions of the British Mycological Society 85: 391-395.

Ding B, YinY, Zhang F, Li Z (2011) Recovery and phylogenetic diversity of culturable fungi associated with marine sponges Clathrina luteoculcitella and Holoxea sp. in the South China Sea. Marine Biotechnology 13: 713-721.

Ellis MB (1965) Dematiaceous Hyphomycetes. VI. Mycological Papers 103: 1-46.

Ellis MB (1971) Dematiaceous Hyphomycetes. Kew: Commonwealth Mycological Institute.

Ernst M, Neubert K, Mendgen K, Wiersel SGR (2011) Niche differentiation of two sympatric species of Microdochium colonizing the roots of common reed, $M$. phragmitis vs. M. bolleyi BMC Microbiology 11: 242-255.

Fernández FA, Huhndorf SM (2005) New species of Chaetosphaeria, Melanopsammella and Tainosphaeria gen. nov. from the Americas. Fungal Diversity 18: 15-57.

Fernández FA, Lutzoni FM, Huhndorf SM (1999) Teleomorphanamorph connections: the new pyrenomycetous genus Carpoligna and its Pleurothecium anamorph. Mycologia 91: 251-262.

Fernández FA, Miller AN, Huhndorf SM, Lutzoni FM, Zoller S (2006) Systematics of the genus Chaetosphaeria and its allied genera: morphological and phylogenetic diversity in north temperate and neotropical taxa. Mycologia 98: 121-130.

Furlanetto C, Dianese JC (1998) Some coelomycetes from Central Brazil. Mycological Research 102: 19-29.

Gams W (2000). Phialophora and some similar morphologically littledifferentiated anamorphs of divergent ascomycetes. Studies in Mycology 45: 187-199.

Gams W, Holubová-Jechová V (1976) Chloridium and some other dematiaceous hyphomycetes growing on decaying wood. Studies in Mycology 13: 1-99.

Gramaje D, Mostert L, Groenewald JZ, Crous PW (2015) Phaeoacremonium: from esca disease to phaeohyphomycosis. Fungal Biology 119: 759-783.

Grove WB (1937) British Stem and Leaf-Fungi (Coelomycetes). Vol. 2. Cambridge: Cambridge University Press.

Habibi A, Banihashemi Z, Mostowfizadeh-Ghalamfarsa R (2015) Phylogenetic analysis of Polystigma and its relationship to Phyllachorales. Phytopathologia Mediterranea 54: 45-54.

Hambleton S, Nickerson NL, Seifert KA (2005) Leohumicola, a new genus of heat-resistant hyphomycetes. Studies in Mycology 53: 29-52.

Hanlin RT (1990) Acerviclypeatus, a new genus for the anamorph of Ophiodothella vaccinii. Mycotaxon 37: 379-384.

Hanlin RT, Goh T-K, Skarshaug AJ (1992) A key to and descriptions of species assigned to Ophiodothella based on the literature. Mycotaxon 44: 103-126.

Hanlin RT, Gonzáles M (2013) Ophiodothella angustissima comb. nov., a new name for Acerviclypeatus poriformans and $O$. vaccinii. Mycotaxon 123: 327-334.

Hausner G, Reid J (2004) The nuclear small subunit ribosomal genes of Sphaeronaemella helvellae, Sphaeronaemella fimicola, 
Gabarnaudia betae, and Cornuvesica falcata: phylogenetic implications. Canadian Journal of Botany 82: 752-762.

Hawksworth DL (2015) Proposals to clarify and enhance the naming of fungi under the International Code of Nomenclature for algae, fungi, and plants. IMA Fungus 6: 199-205; Taxon 64: 858-862.

Hawksworth DL, Gibson IAS, Gams W (1976) Phialophora parasitica associated with disease conditions in various trees. Transactions of the British Mycological Society 66: 427-431.

Hernández-Restrepo M, Gene J, Mena-Portales J, Cano J, Hadrid H, et al. (2014) New species of Cordana and epitypification of the genus. Mycologia 106: 723-734.

Hernández-Restrepo M, Groenewald JZ, Crous PW (2016) Taxonomy and phylogenetic reevaluation of Microdochium, Monographella and Idriella. Persoonia 36: 57-82.

Hironaga M, Nakano K, Yokoyama I, Kitajima J (1989) Phialophora repens, an emerging agent of subcutaneous phaeohyphomycosis in humans. Journal of Clinical Microbiology 27: 394-399.

Holubová-Jechová V (1973a) Lignicolous hyphomycetes from Czechoslovakia 4. Menispora. Folia Geobotanica et Phytotaxonomic 8: 317-336.

Holubová-Jechová V (1973b) Lignicolous hyphomycetes from Czechoslovakia 3. Sporoschisma, Sporoschismopsis and Catenularia. Folia Geobotanica et Phytotaxonomic 8: 209-218.

Holubová-Jechová V, Hennebert GL (1972) Sporoschismopsis, a new genus of lignicolous hyphomycetes. Bulletin du Jardin Botanique National de Belgique 42: 385-391.

Hsieh H-M, Ju Y-M, Rogers JD (2005) Molecular phylogeny of Hypoxylon and closely related genera. Mycologia 97: 844-865.

Hudson HJ (1963) The perfect state of Nigrospora oryzae. Transactions of the British Mycological Society 46: 355-360.

Hughes SJ (1951) Studies on micro-fungi. XI. Some hyphomycetes which produce phialides. Mycological Papers 45: 1-36.

Hughes SJ (1958) Revisiones hyphomycetum aliquot cum appendice de nominibus rejiciendis. Canadian Journal of Botany 36: 727-836.

Hughes SL, Hennebert GL (1963) Microfungi: X. Oedemium, Dimera, Diplosporium, Gongylocladium, and Cladotrichum. Canadian Journal of Botany 41: 773-809.

Jaklitsch WJ, Gardiennet, A, Voglmayr H (2016) Resolution of morphology-based taxonomic delusions: Acrocordiella, Basiseptospora, Blogiascospora, Clypeosphaeria, Hymenopleella, Lepteutypa, Pseudapiospora, Requienella, Seiridium and Strickeria. Persoonia 37: 82-105.

Jeewon R, Cai L, Liew ECY, Zhang K-Q, Hyde KD (2003) Dyrithiopsis lakefuxianensis gen. et sp. nov. from Fuxian Lake, Yunnan, China, and notes on the taxonomic confusion surrounding Dyrithium. Mycologia 95: 911-920.

Johnston PR, Seifert KA, Stone JK, Rossman AY, Maranova L (2014) Recommendations on generic names competing for use in Leotiomycetes (Ascomycota). IMA Fungus 5: 91-120.

Jones EBG, Suetrong S, Sakayaroj J, Bahkali AH, Abdel-Wahab MA, et al. (2015) Classification of marine Ascomycota, Basidiomycota, Blastocladiomycota and Chytridiomycota. Fungal Diversity 73: $1-72$.

Jones EBG, Zuccaro A, Mitchell J, Nakagira A, Chatmala I, et al. (2009) Phylogenetic position of freshwater and marine Sigmoidea species: introducing a marine hyphomycete Halosigmoidea gen. nov. (Halosphaeriales). Botanica Marina 52: 349-359.

Ju Y-M, Hsieh H-M, Dominick S (2016) The Xylaria names proposed by C.G. Lloyd. North American Fungi 11: 1-31.
Khan Z, Gene J, Ahmad S, Cano J, Al-Swieh, N et al. (2013) Coniochaeta polymorpha, a new species from endotracheal aspirate of a preterm neonate, and transfer of Lecythophora species to Coniochaeta. Antonie van Leeuwenhoek 104: 243252.

Kirk PM (1986) New or interesting microfungi XV. Miscellaneous hyphomycetes from the British Isles. Transactions of the British Mycological Society 86: 409-428.

Kohlmeyer J, Volkmann-Kohlmeyer B, Eriksson OE (1997) Fungi on Juncus roemerianus. 9. New obligate and facultative marine Ascomycotina. Botanica Marina 40: 291-300.

Kutorga E, Rukšènienè J, Treigienè A (2006) Microscopic fungi on Carpinus betulus in Lithuania 1. Teleomorphs and associated anamorphs. Botanica Lithuanica 12: 233-241.

Li Q, Wen T-C, Kang J-C, Hyde KD (2015a) A new species of Collodiscula (Xylariaceae) from China. Phytotaxa 205: 187-196.

Li Q, Kang J-C, Hyde KD (2015b) Two new species of the genus Collodiscula (Xylariaceae) from China. Mycological Progress 14: article 52.

Lindqvist JC, Wright JE (1964) Discoxylaria genero nuevo la forma perfecta de Hypocreodendron. Darwiniana 13: 138-143.

Maharachchikumbura SSN, Guo L-D, Cai L, Chukeatirote E, Wu WP, et al. (2012) A multi-locus backbone tree for Pestalotiopsis, with a polyphasic characterization of 14 new species. Fungal Diversity 56: 95-129.

Maharachchikumbura SSN, Hyde KD, Groenewald JZ, Xu J, Crous PW (2014) Pestalotiopsis revisited. Studies in Mycology 79: 121-186.

Maharachchikumbura SSN, Hyde KD, Jones EBG, McKenzie EHC, Huang S-K, et al. (2015) Towards a natural classification and backbone tree for Sordariomycetes. Fungal Diversity 72: 199301.

Markovskaja S, Treigiené A (2007) A new and a rare species of Cryptadelphia and their Brachysporium anamorphs. Nova Hedwigia 84: 495-501.

McNeill J, Barrie FR, Burdet HM, Demoulin V, Hawksworth DL, et al. (2006) International Code of Botanical Nomenclature (Vienna Code). [Regnum Vegetabile no. 146.] Ruggell: A. R. G. Gantner Verlag.

McNeill J, Barrie FF, Buck WR, Demoulin V, Greuter W, et al. (eds) (2012) International Code of Nomenclature for algae, fungi, and plants (Melbourne Code). [Regnum vegetabile no. 154.] Königstein: Koeltz Scientific Books.

Meyer WM, Dooley JR, Kwon-Chung KJ (1975) Mycotic granuloma caused by Phialophora repens. American Journal of Clinical Pathology 64: 549-555.

Mhmoud NA, Abdalla AS, Fahal AH, de Hoog GS, Gerrits van den Ende AH et al. (2012) Pleurostomophora ochracea, a novel agent of human eumycetoma with yellow grains. Journal of Clinical Microbiology 50: 2987-2994.

Miller AN, Huhndorf SM (2004). A natural classification of Lasiosphaeria based on nuclear LSU rDNA sequences. Mycological Research 108: 26-34.

Moshrefi-Zarandi D, Aminaee MM, Sharzei A, Rezaee S (2014) First report of rosemary leaf spot caused by Nigrospora oryzae in Iran. New Disease Reports 30: 27.

Mostert L, Crous PW, Groenewald JZ, Gams W, Summerbell RC (2003) Togninia (Calosphaeriales) is confirmed as teleomorph of Phaeoacremonium by means of morphology, sexual compatibility and DNA phylogeny. Mycologia 95: 646-659. 
Mostert L, Groenewald JZ, Summerbell RC, Gams W, Crous PW (2006) Taxonomy and pathology of Togninia (Diaporthales) and its Phaeoacremonium anamorphs. Studies in Mycology 54: 1-115.

Mugambi G, Huhndorf SM (2008) A new species of Melanochaeta from Kenya. Sydowia 60: 261-266.

Mugambi GK, Huhndorf SM (2010) Multigene phylogeny of the Coronophorales: morphology and new species in the order. Mycologia 102: 185-210.

Müller E (1986) On the genus Diachora J. Müller. Transactions of the Botanical Society of Edinburgh 45 (Supplement 1): 69-75.

Müller E, von Arx JA (1962) Die Gattungen der didymosporen Pyrenomyceten. Beiträge zur Kryptogamenflora der Schweiz 11(2): 1-922.

Müller E, Samuels GJ (1982) Anamorphs of pyrenomycetous ascomycetes I. Rhamphoria NiessI and Trichosphaerella Bommer et al. Sydowia 35: 143-149

Müller E, Samuels G (1982) Anamorphs of pyrenomycetous ascomycetes. II. Porosphaerella gen. nov. and its Cordana anamorph. Sydowia 35: 150-154.

Nag Raj TR (1975) Genera coelomycetum. XI. Hyalotia, Hyalotiella, and Hyalotiopsis. Canadian Journal of Botany 53: 1615-1624.

Nag Raj TR (1993) Coelomycetous Anamorphs with Appendagebearing Conidia. Waterloo: Mycologue Publications.

Nag Raj TR, Kendrick B (1986) Ellurema gen. nov., with notes on Lepteutypa cisticola and Seiridium canariense. Sydowia 38: 178-193.

Nakagiri A, Tokura R (1982) A new marine ascomycete and its anamorph from Japan. Transactions of the Mycological Society of Japan 23: 101-110.

Nawawi A, Kuthubutheen AJ (1989) Canalisporium, a new genus of lignicolous hyphomycetes from Malaysia. Mycotaxon 34: 475-487.

Nonaka K, Ishit T, Shiomi K, Omura S, Masume R (2013) Virgaria boninensis, a new hyphomycete (Xylariaceae) from soils in the Bonin Islands, Japan. Mycoscience 54: 394-399.

Nonaka K, Miyazaki H, Iwatsuki M, Shiomi K, Tomoda $\mathrm{H}$ et al. (2012) Staphylotrichum boninense, a new hyphomycete (Chaetomiaceae) from soils in the Bonin Islands, Japan. Mycoscience 53: 312-318.

Norphanphoun C, Maharachchikumbura SSN, Daranagama A, Bulgakov TS, Bhat DJ, et al. (2015) Towards a backbone tree for Seimatosporium, with S. physocarpi sp. nov. Mycosphere 6 : 385-400.

Okane I, Nakagiri A (2007) Taxonomy of an anamorphic xylariaceous fungus from a termite nest found together with Xylaria angulosa. Mycoscience 48: 240-249.

Palm ME, Gams W, Nirenberg HI (1995) Plectosporium, a new genus for Fusarium tabacinum, the anamorph of Plectosphaerella cucumerina. Mycologia 87: 397-406.

Perdomo H, Garcia D, Gene J, Sutton DA, Summerbell R et al. (2013) Phialemoniopsis, a new genus of Sordariomycetes, and new species of Phialemonium and Lecythophora. Mycologia 105: 398-421.

Peršoh D, Melcher M, Flessa F, Rambold G (2010) First fungal community analyses of endophytic ascomycetes associated with Viscum album ssp. austriacum and its host Pinus sylvestris. Fungal Biology 114: 585-596.

Petrini L (2013) Rosellinia - a world monograph. Bibliotheca Mycologica 205: 1-410.

Proffer TJ (1988) Xylaria root rot of urban trees caused by Xylaria polymorpha. Plant Disease 72: 79
Punithalingam E (1970) Studies on Sphaeropsidales in culture. Mycological Papers 119: 1-24.

Quandt CA, Kepler RM, Gams W, Araújo JPM, Ban S, et al. (2014) Phylogenetic-based nomenclatural proposals for Ophiocordycipitaceae (Hypocreales) with new combinations in Tolypocladium. IMA Fungus 5: 121-134.

Raja HA, Fournier J, Shearer CA, Miller AN (2012) Freshwater ascomycetes: Coniochaeta gigantospora sp. nov. based on morphological and molecular data. Mycoscience 53: 373-380.

Rambelli A, Onofri S (1987) New species of Kylindria and Xenokylindria and notes on Cylindrotrichum (Hyphomycetes). Transactions of the British Mycological Society 88: 393-397.

Ranghoo VM, Tsui CKM, Hyde KD (2001) Brunneosporella aquatica gen. et sp. nov., Aqualignicola hyalina gen. et sp. nov., Jobellisia viridifusca sp. nov. and Porosphaerellopsis bipolaris sp. nov. (Ascomycetes) from submerged wood in freshwater habitats. Mycological Research 105: 625-633.

Réblová M (1999) Studies in Chaetosphaeria sensu lato I. The genera Chaetosphaerella and Tengiomyces gen. nov. of the Helminthosphaeriaceae. Mycotaxon 70: 387-420.

Réblová M (2000) The genus Chaetosphaeria and its anamorphs. Studies in Mycology 45: 149-168.

Réblová M (2011) New insights into the systematics and phylogeny of the genus Jattaea and similar fungi of the Calosphaeriales. Fungal Diversity 49: 167-198.

Réblová M (2014) Sporoschismopsis angustata sp. nov., a new holomorph species in the Reticulascaceae (Glomerellales), and a reappraisal of Sporoschismopsis. Mycological Progress 13: 671-681.

Réblová M, Barr ME, Samuels GJ (1999) Chaetosphaeriaceae, a new family for Chaetosphaeria and its relatives. Sydowia 51: 49-70.

Réblová M, Gams W (1999) Teleomorph-anamorph connections in ascomycetes. 1. Cylindrotrichum and Cacumisporium anamorphs of Chaetosphaeria. Czech Mycology 51: 1-40.

Réblová M, Gams W, Seifert KA (2011a) Monilochaetes and allied genera of the Glomerellales, and a reconsideration of families in the Microascales. Studies in Mycology 68: 163-191.

Réblová M, Gams W, Štěpánek V (2011b) The new hyphomycete genera Brachyalara and Infundichalara, the similar Exochalara and species of Phialophora' sect. Catenulatae' (Leotiomycetes). Fungal Diversity 46: 67-86.

Réblová M, Jaklitsch WM, Réblová K, Štěpánek V (2015) Phylogenetic reconstruction of the Calosphaeriales and Togniniales using five genes and predicted RNA secondary structures of ITS, and Flabellascus tenuirostris gen. et sp. nov. PLos One 10(12): e0144616.

Réblová M, Mostert L, Gams W, Crous PW (2004) New genera in the Calosphaeriales: Togniniella and its anamorph Phaeocrella, and Calosphaeriophora as anamorph of Calosphaeria. Studies in Mycology 50: 533-550.

Réblová M, Mostert L (2007) Romellia is congeneric with Togninia and description of Conidiotheca gen. nov. for one species of this genus with polysporous asci. Mycological Research 111: 299-307.

Réblová M, Seifert KA (2004a) Conioscyphascus, a new ascomycetous genus for holomorphs with Conioscypha anamorphs. Studies in Mycology 50: 95-108.

Réblová M, Seifert KA (2004b) Cryptadelphia (Trichosphaeriales), a new genus for holomorphs with Brachysporium anamorphs, and clarification of the taxonomic status of Wallrothiella. Mycologia 96: 343-367. 
Réblová M, Seifert KA (2007) A new fungal genus, Teracosphaeria, with a phialophora-like anamorph (Sordariomycetes, Ascomycota). Mycological Research 111: 287-298.

Réblová M, Seifert KA, Fournier J, Štěpánek V (2016) Newly recognised lineages of perithecial ascomycetes: the new orders Conioscyphales and Pleurotheciales. Persoonia 37: 57-81.

Réblová M, Winka K (2000) Phylogeny of Chaetosphaeria and its anamorphs based on morphological and molecular data. Mycologia 92: 939-954.

Rodrigues de Cruz MC, Marques MFO, Guzmão LFP (2014) Conidial fungi from the semi-arid catinga biome of Brazil. The genus Menisporopsis. Acta Botanica Brasilica 28: 339-345.

Rogers JD (1984) Xylaria cubensis and its anamorph Xylocoremium flabelliforme, Xylaria allantoidea, and Xylaria poitei in continental United States. Mycologia 76: 912-923.

Rogers JD, Ju Y-M (2002) Ascovirgaria occulta gen. et sp. nov., Jumillera hawaiiensis sp. nov, and Lopadostoma hawaiianum sp. nov. from Hawaii. Canadian Journal of Botany 80: 478-481.

Rogers JD, Ju Y-M, Hemmes DE (1997) Xylaria moelleroclavus sp. nov. and its Moelleroclavus anamorphic state. Mycological Research 101: 345-348.

Rogers JD, Ju Y-M, San Martin Gonzalez F (1995) Discoxylaria myrmecophila and its Hypocreodendron anamorph. Mycologia 87: 41-45.

Rojas El, Rehner SA, Samuels GJ, Van Bael SA, Herre EA et al. (2010) Colletotrichum gloeosporioides s.l. associated with Theobroma cacao and other plants in Panama: multilocus phylogenies distinguish host-associated pathogens from asymptomatic endophytes. Mycologia 102: 1318-1338.

Rolshausen PE, Mahoney NE, Molyneux RJ, Gubler WD (2006) A reassessment of the species concept in Eutypa lata, the causal agent of Eutypa dieback of grapevine. Phytopathology 96: 367-377.

Rossman AY, Seifert KA, Samuels GJ, Minnis AM, Schroers H-J, et al. (2013) Genera in Bionectriaceae, Hypocreaceae, and Nectriaceae (Hypocreales) proposed for acceptance or rejection. IMA Fungus 4: 41-51.

Rossman AY, Adams GC, Cannon PF, Castlebury LA, Crous PW et al. (2015a) Recommendations of generic names in Diaporthales competing for protection or use. IMA Fungus 6: 145-154.

Rossman AY, Crous PW, Hyde KD, Hawksworth DL, Aptroot A, et al. (2015b) Recommended names of pleomorphic genera in Dothideomycetes. IMA Fungus 6: 507-523.

Samson RA (1974) Paecilomyces and some allied hyphomycetes. Studies in Mycology 6: 1-119.

Samson RA, Visagie CM, Houbraken J, Hong S-B, Hubka V, et al. (2014) Phylogeny, identification and nomenclature of the genus Aspergillus. Studies in Mycology 78: 141-173.

Samuels GJ, Müller E (1978) Life-history studies of Brazilian ascomycetes. 1. Two new genera of the Sphaeriaceae having, respectively, Sporoschisma-like and Codinaea anamorphs. Sydowia 31: 126-136.

Samuels GJ, Müller E (1980) Life history studies of Brazilian ascomycetes 8. Thamnomyces chordalis (anam.: Nodulisporium) and Camillea bacillum (anam.: Geniculosporium) with notes on taxonomy of the Xylariaceae. Sydowia 33: 274-281.

Samuels GJ, McKenzie EHC, Buchanan DE (1981) Ascomycetes of New Zealand 3. Two new species of Apiospora and their Arthrinium anamorphs on bamboo. New Zealand Journal of Botany 19: 137-149.

Samuels GJ, Rogers JD, Nagasawa E (1987) Studies in the
Amphisphaeriaceae (sensu lato) 11. Collodiscula japonica and its anamorph, Acanthodochium collodisculae. Mycotaxon 28: 453-459.

Schoch CL, Sung GH, Volkmann-Kohlmeyer B, Kohlmeyer J, Spatafora JW (2007) Marine fungal lineages in the Hypocreomycetidae. Mycological Research 111: 154-162.

Schol-Schwarz MB(1970). Revision of the genus Phialophora. Persoonia 6: 59-94.

Seifert KA (1987) Stromatographium and Acrostroma gen. nov.: two tropical hyphomycete genera with distinctive synnema anatomies. Canadian Journal of Botany 65: 2196-2201.

Seifert KA, Gams W, Louis-Seize GW (2002) Arthroxylaria elegans, a new coprophilous anamorphic fungus allied with the Xylariaceae, with notes on the genus Bisporostilbella. Czech Mycology 53: 297-307.

Senanayake IC, Maharachchikumbura SSN, Hyde KD, Bhat JD, Jones EBG, et al. (2015) Towards unraveling relationships in Xylariomycetidae (Sordariomycetes). Fungal Diversity 73: 73-144.

Shenoy BD, Jeewon R, Wu WP, Bhat DJ, Hyde KD (2006) Ribosomal and RPB2 DNA sequence analyses suggest that Sporidesmium and morphologically similar genera are polyphyletic. Mycological Research 110: 916-928.

Shoemaker RA, Müller E, Morgan-Jones G (1966) Fuckel's Massaria marginata and Seiridium marginatum Nees ex Steudel. Canadian Journal of Botany 44: 247-254.

Shoemaker RA (1964) Seimatosporium (= Cryptostictis) parasites of Rosa, Vitis, and Cornus. Canadian Journal of Botany 42: 411421.

Sivanesan A (1983) Studies on ascomycetes. Transactions of the British Mycological Society 81: 313-332.

Sivichai S, Hywel-Jones NL, Somrithipol S (2000) Lignicolous freshwater Ascomycota from Thailand: Melanochaeta and Sporoschisma anamorphs. Mycological Research 104: 478-485.

Sri-indrasutdhi V, Boonyuen N, Suetrong S, Chuaseeharonnachai C, Sivichai S, et al. (2010) Wood-inhabiting freshwater fungi from Thailand: Ascothailandia grenadoidia gen. et sp. nov., Canalisporium grenadoidia sp. nov. with a key to Canalisporium species (Sordariomycetes, Ascomycota). Mycoscience 51: 411420.

Stadler M, Kuhnert E, Peršoh D, Fournier J (2013) The Xylariaceae as model example for a unified nomenclature following the "One fungus-one name" (1F1N) concept. Mycology 4: 5-21.

Stadler M, Læssøe T, Fournier J, Decock C, Schmieschek B, et al. (2014). A polyphasic taxonomy of Daldinia (Xylariaceae). Studies in Mycology 77: 1-143.

Subramanian CV, Sekar G (1986) Pseudocercophora ingoldii gen. et sp. nov. and its Mammaria anamorph. Journal of the Singapore National Academy of Sciences 15: 58-60.

Sutton BC (1980) The Coelomycetes; Fungi Imperfecti with pycnidia, acervuli and stromata. Kew: Commonwealth Mycological Institute.

Tanaka K, Endo M, Hirayama K, Okane I, Hosoya T, et al. (2011) Phylogeny of Discosia and Seimatosporium and introduction of Adisciso and Immersidiscosia genera nova. Persoonia 26: 85-98.

Tang AM, Jeewon R, Hyde KD (2007) Phylogenetic utility of protein (RPB2, beta-tubulin) and ribosomal (LSU, SSU) gene sequences in the systematics of Sordariomycetes, Ascomycota, Fungi. Antonie van Leeuwenhoek 91: 327-349.

Trouillas FP, Lorber JD, Peduto F, Grant J, Coates WW, et al. (2010a) 
First report of Calosphaeria pulchella associated with branch dieback of sweet cherry trees in California. Plant Disease 94: 1167.

Trouillas FP, Urbez-Torres JR, Gubler WD (2010b). Diversity of diatrypaceous fungi associated with grapevine canker diseases in California. Mycologia 102: 319-336.

Untereiner WA, Debois V, Naveau FA (2001) Molecular systematics of the ascomycete genus Farrowia (Chaetomiaceae). Canadian Journal of Botany 79: 321-333.

Vakili NG (1989) Gonatobotrys simplex and its teleomorph, Melanospora damnosa. Mycological Research 93: 67-74.

Vijaykrishna D, Mostert L, Jeewon R, Gams W, Hyde KD, et al. (2004) Pleurostomophora, an anamorph of Pleurostoma (Calosphaeriales), a new anamorph genus morphologically similar to Phialophora. Studies in Mycology 50: 387-395.

Visagie CM, Houbraken J, Frisvad JC, Hong S-B, Klaassen CHW, et al. (2014) Identification and nomenclature of the genus Penicillium. Studies in Mycology 78: 343-371.

Weber E, Gorke C, Begerow D (2002) The Lecythophora-Coniochaeta complex II. Molecular studies based on sequences of the large subunit of ribosomal DNA. Nova Hedwigia 74: 187-200.
Weir BS, Johnston PR, Damm U (2012) The Colletotrichum gloeosporioides species complex. Studies in Mycology 73: 115180.

Wijayawardene DNN, McKenzie EHC, Hyde KD (2012) Towards incorporating anamorphic fungi in a natural classificationchecklist and notes for 2011. Mycosphere 3: 157-228.

Zelski S, Do C, Balto JA, Raja HA, Miller AN, et al. (2014a) Some dematiaceous freshwater microfungi from Perú and their previously unknown phylogenetic relationships based on $28 \mathrm{~S}$ nrDNA. IMA Fungus 5: 425-438.

Zelski SE, Raja HA, Miller AN, Shearer CA (2014b) Conioscypha peruviana sp. nov., its phylogenetic placement based on $28 \mathrm{~S}$ rRNA gene, and a report of Conioscypha gracilis comb. nov. from Peru. Mycoscience 56: 319-325.

Zhang N, Luo J, Rossman A, Aoki T, Chuma I, et al. (2016) Generic names in Magnaporthales. IMA Fungus 7: 155-159. 